\title{
Rho-Family Small GTPases: From Highly Polarized Sensory Neurons to Cancer Cells
}

\author{
Takehiko Ueyama ${ }^{(1)}$ \\ Laboratory of Molecular Pharmacology, Biosignal Research Center, Kobe University, Kobe 657-8501, Japan; \\ tueyama@kobe-u.ac.jp
}

Received: 28 December 2018; Accepted: 23 January 2019; Published: 28 January 2019

\begin{abstract}
The small GTPases of the Rho-family (Rho-family GTPases) have various physiological functions, including cytoskeletal regulation, cell polarity establishment, cell proliferation and motility, transcription, reactive oxygen species (ROS) production, and tumorigenesis. A relatively large number of downstream targets of Rho-family GTPases have been reported for in vitro studies. However, only a small number of signal pathways have been established at the in vivo level. Cumulative evidence for the functions of Rho-family GTPases has been reported for in vivo studies using genetically engineered mouse models. It was based on different cell- and tissue-specific conditional genes targeting mice. In this review, we introduce recent advances in in vivo studies, including human patient trials on Rho-family GTPases, focusing on highly polarized sensory organs, such as the cochlea, which is the primary hearing organ, host defenses involving reactive oxygen species (ROS) production, and tumorigenesis (especially associated with RAC, novel RAC1-GSPT1 signaling, RHOA, and RHOBTB2).
\end{abstract}

Keywords: CDC42; congenital (hereditary) diseases; DFNA1; DIA1 (DIAPH1); GSPT1 (eRF3a); hearing; NADPH oxidase (Nox); RAC; RHOA; reactive oxygen species (ROS)

\section{Introduction}

The small GTPases (also known as small G proteins ( 21 kDa)) of the Rho-family (Rho-family GTPases) form a subfamily of the Ras superfamily of small GTPases. Human and murine Rho-family GTPases include 21 members subdivided into eight families classified as typical (classical) or atypical depending on their mode of regulation [1] (Table 1). Rho, Rac, Cdc42, and RhoF/RhoD are members of the classical subfamilies (Table 1) and their functions are regulated by cycling between an inactive GDP-bound form and an active GTP-bound form. Rnd, RhoH, RhoU/RhoV, and RhoBTB are atypical subfamilies and predominantly exist in the GTP-bound-form. The GTP-bound status is regulated by guanine nucleotide exchange factors (GEFs), GTPase-activating proteins (GAPs), and Rho-specific guanine nucleotide dissociation inhibitors (RhoGDIs) [2,3]. In humans, there are $\sim 80$ RhoGEFs classified into the Dbl family (69 members) and the DOCK family (11 members) [2,3]. The RhoGDI family comprises the RhoGDI $\alpha$, RhoGDI $\beta$, and RhoGDI $\gamma$ subtypes [4]. RhoGDI $\alpha$ is ubiquitously expressed, whereas RhoGDI $\beta$ is expressed mainly in hematopoietic cells and also in cancer cells. RhoGDI $\gamma$ is expressed primarily in the brain. RhoGDI $\alpha$ and RhoGDI $\beta$ are expressed in phagocytes. The atypical subfamily of Rho-family GTPases is regulated by expression, post-transcriptional modifications, and/or interaction with other proteins but not by GEFs or GAPs [1,5]. Not all Rho-family GTPases are regulated by RhoGDIs [1,6]. 
Table 1. Knockout (KO) mice availability, congenital diseases, and tumorigenesis-associated Rho-family GTPases. Blue indicates typical (classical) Rho-family GTPases including the Rho, Rac, Cdc42, and RhoD/RhoF subfamilies. Red indicates atypical Rho-family GTPases including the Rnd, RhoH, RhoU/RhoV, and RhoBTB subfamilies. CNS: central nervous system, HD: host defenses, TKS: Takenouchi-Kosaki syndrome. + : conditional floxed mice. ${ }^{\mathrm{C}}$ : conventional $\mathrm{KO}$ mice.

\begin{tabular}{|c|c|c|}
\hline Name (Synonym) & KO Mice Availability & Tumorigenesis \\
\hline \multicolumn{3}{|c|}{ Rho Subfamily } \\
\hline RhoA & $+[7]$ & $\begin{array}{l}\text { lymphomas }[8-11] \text {, } \\
\text { gastric cancer }[12,13] \text {, } \\
\text { head \& neck squamous } \\
\text { cell carcinoma }[14,15]\end{array}$ \\
\hline RhoB & $+^{\mathrm{C}}[16]$ & $\begin{array}{c}\text { induction [17] } \\
\text { and suppression }[17,18]\end{array}$ \\
\hline RhoC & $+_{+}^{C}[19]$ & reported [14] \\
\hline \multicolumn{3}{|c|}{ Rac Subfamily } \\
\hline Rac1 & $+($ CNS anomalies $)[20]$ & $\begin{array}{c}\text { melanoma }[21,22] \\
\text { head \& neck squamous } \\
\text { cell carcinoma }[14,15]\end{array}$ \\
\hline Rac2 & $\begin{array}{c}\text { + (HD deficiency }) \\
{[23-26]}\end{array}$ & reported $[14,27]$ \\
\hline Rac3 & $+_{+}^{\mathrm{C}}$ & reported [14] \\
\hline RhoG & $+^{\mathrm{C}}[28]$ & \\
\hline \multicolumn{3}{|c|}{ Cdc42 Subfamily } \\
\hline Cdc42 & $+(\mathrm{TKS})[29-32]$ & reported [14] \\
\hline RhoJ (TCL) & $+[33]$ & \\
\hline RhoQ (TC10) & $+[34]$ & \\
\hline \multicolumn{3}{|c|}{ RhoD/RhoF Subfamily } \\
\hline \multicolumn{3}{|l|}{ RhoD } \\
\hline \multirow[t]{2}{*}{ RhoF (Rif) } & $+[35]$ & \\
\hline & Rnd Subfamily & \\
\hline \multicolumn{3}{|l|}{ Rnd1 } \\
\hline \multicolumn{3}{|l|}{ Rnd2 (RhoN) } \\
\hline \multicolumn{3}{|l|}{ Rnd3 (RhoE) } \\
\hline \multicolumn{3}{|c|}{ RhoH Subfamily } \\
\hline RhoH & $+^{\mathrm{C}}[36]$ & lymphoma $[37,38]$ \\
\hline \multicolumn{3}{|c|}{ RhoU/RhoV Subfamily } \\
\hline \multicolumn{3}{|l|}{ RhoU } \\
\hline \multicolumn{3}{|l|}{ RhoV } \\
\hline \multicolumn{3}{|c|}{ RhoBTB Subfamily } \\
\hline \multicolumn{3}{|l|}{ RhoBTB1 } \\
\hline RhoBTB2 & $+($ CNS anomalies) [39] & suppression [5] \\
\hline RhoBTB3 & ${ }_{+}^{+C}[40]$ & \\
\hline
\end{tabular}

Rho-family GTPases have various physiological functions in cytoskeletal regulation, cell polarity establishment, neuronal cell development, cell proliferation/division, cell movement/migration, cell-cell junction establishment, endosome trafficking, transcriptional regulation, reactive oxygen species (ROS) production, and tumorigenesis [41-45]. Rac, Cdc42, and RhoA are characterized both at the cellular (in vitro) and live animal (in vivo) levels. However, there is growing evidence for other Rho-family GTPases. Moreover, information about the functions of Rho-family GTPases in vivo is increasing and is based on various tissue (cell)-specific genetically engineered mouse models. In this review, we focus mainly on recent advances in research on Rho-family GTPases involved in highly polarized sensory organs / cells and ROS production as well as Rho-family GTPases related with cancer cells, which undergo uncontrolled growth and may be undifferentiated and/or disdifferentiated. 


\section{Hearing Function and Beyond}

The organ of Corti (OC), the primary organ in the cochlea responsible for our sense of hearing, detects sounds by "electromechanical transduction (MET)" [46,47]. It has highly polarized sensory epithelial cells known as cochlear "hair cells (HCs)" and supporting cells (SCs) (Figure 1A). Cochlear HCs are arranged in a single row of inner HCs (IHCs) and three rows of outer HCs (OHCs). They have specialized actin-based structures such as stereocilia, apical junctional complexes (AJCs), and cuticular plates $[48,49]$. Sound-induced vibrations are detected by the directed and coordinated deflection of the stereocilia. Therefore, well-organized morphological and functional regulation is essential for the establishment and maintenance of hearing.

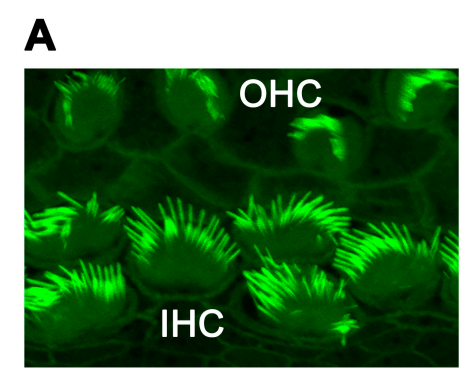

B

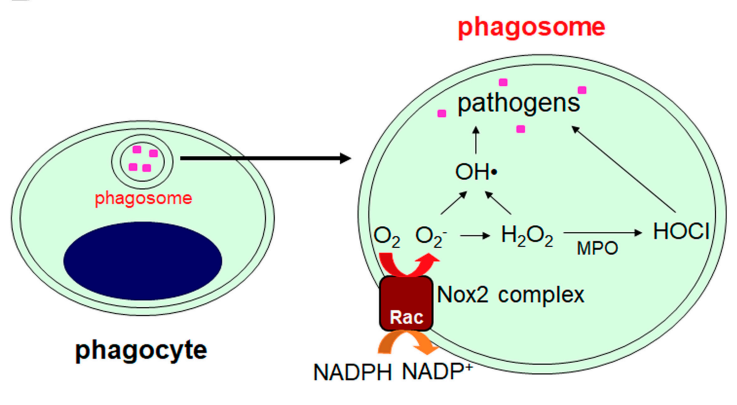

C

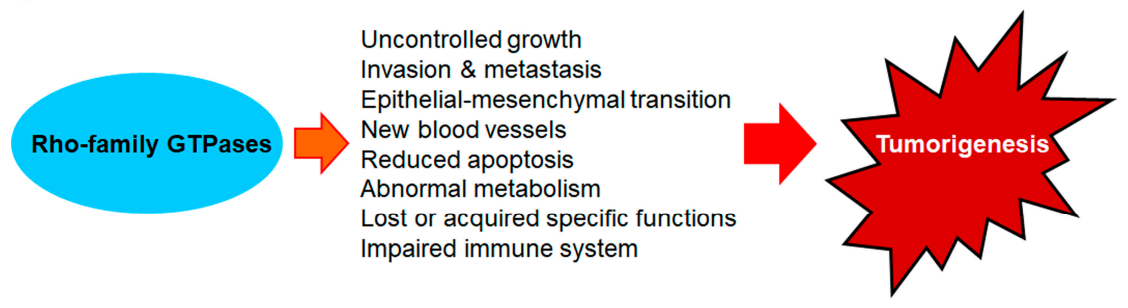

Figure 1. An overview of the main focus points of this review. (A) hearing function, (B) host defenses using ROS and Rac-dependent Noxs, and (C) tumorigenesis. (A) Inner hair cells (IHCs) and outer hair cells (OHCs) obtained from the wild-type cochlea at the age of P5 (stained by Alexa Fluor 488-labelled phalloidin). The illustration represents the mosaic alignment of HCs and supporting cells (SCs). AJCs: apical junctional complexes between HC and SC. (B) The illustration on the left shows phagocytes with a phagosome containing internalized pathogens (indicated by pink square). The middle illustration shows the magnified phagosome with a Nox 2 complex (Rac is one of six components) on the membrane. Superoxide $\left(\mathrm{O}_{2}{ }^{-}\right)$and reactive oxygen species (ROS) are generated in the phagosome. The illustration on the right shows the otoliths on the otolithic membrane in the vestibule. Superoxide from Nox3 is essential for the synthesis of otolith; however, the origin of superoxide (that is Nox3-expressing cells in the inner ear) is still controversial. (C) The scheme represents how Rho-family GTPases are involved in tumorigenesis. 


\subsection{Role and Function of Rac in Hearing}

The function of Rac1 in hearing was elucidated using Foxg1-Cre or Pax2-Cre mice with Rac1 knockout (KO). The Rac1-KO (Foxg1-Cre;Rac flox/flox and Pax2-Cre;Rac1 ${ }^{\text {floxfflox }}$ ) mice showed embryonic lethality, incomplete development of HC planar cell polarity (PCP), and abnormal and fragmented hair bundles [50]. Mice with Rac1 and Rac3 double knockout (DKO) presented with exacerbated Rac1-KO phenotypes [51]. These pioneering studies unveiled the functions of Rac in the cochlea. However, Foxg1 [52,53] and Pax2 [54] are activated before Atoh1 in the cochlea, the master regulator of HC differentiation [55]. These genes are also active in the telencephalon (Foxg1), the brain stem, and throughout the OC epithelia including the HCs, SCs, and their precursors [56]. Further studies are required to reveal the specific functions of Rac in the HCs.

\subsection{Role and Function of $C d c 42$ in Hearing}

We recently reported that Cdc42 plays essential roles in the maintenance of cochlear HCs. We generated Cdc42-KO mice under the control of the Atoh1 promoter (Atoh1-Cre;Cdc42floxfflox [57]. After normal morphological maturation, the $C d c 42-\mathrm{KO}$ mice showed progressive sensorineural hearing loss (SNHL), particularly at high frequencies, and HC loss accompanied by various stereociliary abnormalities starting at postnatal day 14 (P14) (scattered, short, long, and fused) predominantly at the IHCs of the basal turn. Cdc42 acts on the membranes covering the stereocilia (especially the upper half) and the apical junctional complexes (AJCs) in the cochlear HCs [57]. Cdc42 functions at the AJCs as a complex with atypical subfamily of protein kinase Cs (aPKCs) [57]. However, its maintenance mechanism at the stereociliary membranes remains unknown. Active Cdc42 at the upper half of the stereociliary membranes may be involved in an "tip turnover" model of stereolilia, in which actin turnover in stereocilia occurs only at the tips, but not shafts [47,58-60]. The Cdc42 expression levels in the HCs resembled those in SCs [61]. Another group examined the Cdc42-KO

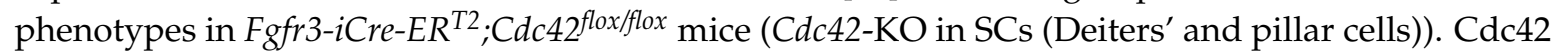
was knocked out using Fgfr3-iCre-ER ${ }^{T 2}$ mice, in which Cre functioned with the assistance of tamoxifen administration (between P2 and P4 or P16 and P18). The mice presented with impaired apical polarization of SCs, no cochlear HC loss, and impaired wound healing in the SCs after ototoxin administration in the adults [62]. To examine the function of Cdc42 in HCs (especially OHCs), different tamoxifen administration intervals were applied at E13.5 and E14.5 or at E15.5 and E16.5 against

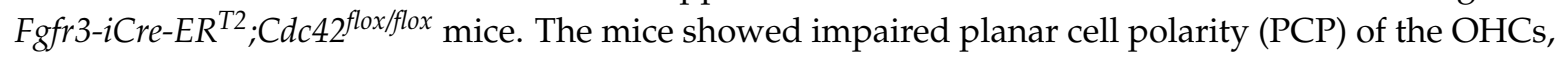
fragmented stereociliary bundles, short stereocilia, and scattered OHC loss at P6 [63]. Their phenotypes

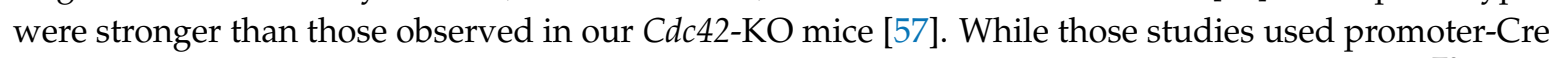
mice, ours tested Atoh1-Cre transgenic mice. However, another group used Fgfr3-iCre-ER ${ }^{T 2}$ mice. Following are possible reasons why the phenotypes differed between these groups: (1) although the Atoh 1 and Fgfr3 promoters function in both HCs and SCs, the Atoh1 promoter operates predominantly in the former rather than the latter [56,64,65]; (2) unequal proportions of Cdc42 $\mathrm{KO}$ in the HCs and SCs may differentially affect the HC phenotypes since HC-SC interaction is a critical step in terminal HC differentiation [55].

\subsection{Hearing in Patients with RAC1 or CDC42 Mutations}

The physiological relevance of RAC and CDC42 has received increased attention. Patients have been identified with mutations in CDC42, RAC1, and RAC2. Takenouchi and Kosaki [29,30] and Motokawa et al. [31] reported three patients with a heterozygous missense point mutation in CDC42, which results in a p.Y64C mutant of CDC42. Their phenotypes included SNHL, macrothrombocytopenia (MTC), dysmorphic craniofacial features, lymphedema, and various CNS abnormalities such as ventriculomegaly and hypoplastic cerebellum (Figure 2). Martinelli et al. reported 15 patients from 13 unrelated families sharing nine a clinically heterogeneous but overlapping phenotype associated with heterozygous missense point mutations in CDC42 mutations resulting in p.I21T, p.Y23C, p.Y64C, p.R66G, p.R68Q, 
p.C81F, p.83P, p.A159V, and p.Q171K mutants [32]. Patients with CDC42 mutants are now diagnosed with the Takenouchi-Kosaki syndrome (TKS) (Figure 2). Those with a heterozygous mutant (p.D57N) in RAC2 (a hematopoietic cell-specific RAC isoform) presented with recurrent infection and defective neutrophil functions [23,24]. Patients with a homozygous nonsense mutation in RAC2 (p.W56X) showed B-lymphocyte, T-lymphocyte, and neutrophil abnormalities [26]. In addition, p.C18Y, p.N39S, p.V51M, p.V51L, p.Y64D, p.P73L, and p.C157Y mutants of RAC1 were recently reported in seven patients [20]. They displayed various CNS abnormalities, including hypoplasia of the medial cerebellum and abnormal corpus callosum (Figure 2). Only one patient (p.Y64D) presented with SNHL. Hypoplasias of the medial cerebellum and corpus callosum are consistent with the results of previous studies using mice with DKO of Rac1 and Rac3 in the cerebellar granule neurons (Atoh1-Cre;Rac1 ${ }^{\text {flox/flox }}$;Rac3 ${ }^{-/-}$) [66], Rac1 KO in the cerebellar neurons (Nestin-Cre;Rac1 flox/flox) [67], and Rac1 KO in the telencephalon (Foxg1-Cre;Rac1 $1^{\text {flox/flox }}$, Dlx6/6-Cre;Rac1 $1^{\text {flox/flox }}$, and Emx1-Cre;Rac1 ${ }^{\text {flox/flox }}$ ) [68,69] (Figure 2). Rac1-KO in the telencephalon (Foxg1-Cre;Rac1 ${ }^{\text {flox/flox }}$ ) was also associated with microcephaly [70]. However, the mechanisms by which heterozygous CDC42 and RAC1 mutants induce the specific phenotypes remain unknown. Does each mutant have the same fundamental mechanism such as a gain-of-function or dominant negative effect? Is the dysfunction associated with each mutant compensated by intact molecules in the same subfamily (such as RHOJ and/or RHOQ for CDC42, and RAC2, RAC3, and/or RHOG for RAC1)? Further studies are required to answer these questions.

Cerebellar development Corpus callosum development GABAergic network establishment Bone formation \& resorption Hair follicle development Immune system (B-cell) development
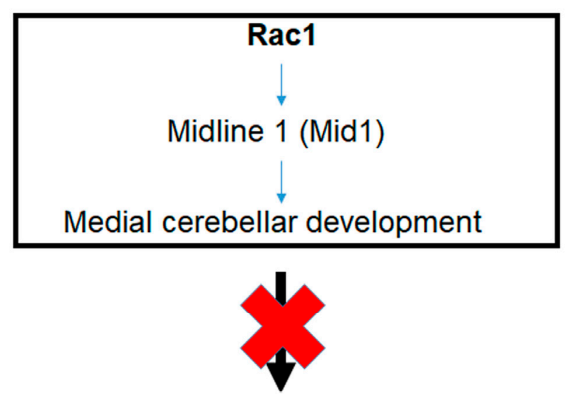

Symptoms of patients with Rac1 mutant Various CNS anomalies (microcephaly or macrocephaly, medial cerebellar hypoplasia, hypoplasia of corpus callosum)
Retinal development

Establishing polarity of the neuroepithelium

Cerebellar development

Bone formation \& resorption

Craniofacial development

Hair follicle development

Immune system (B- and T-cell) development

Blood cells development, including platelet Angiogenesis and lymphatic lumen maintenance

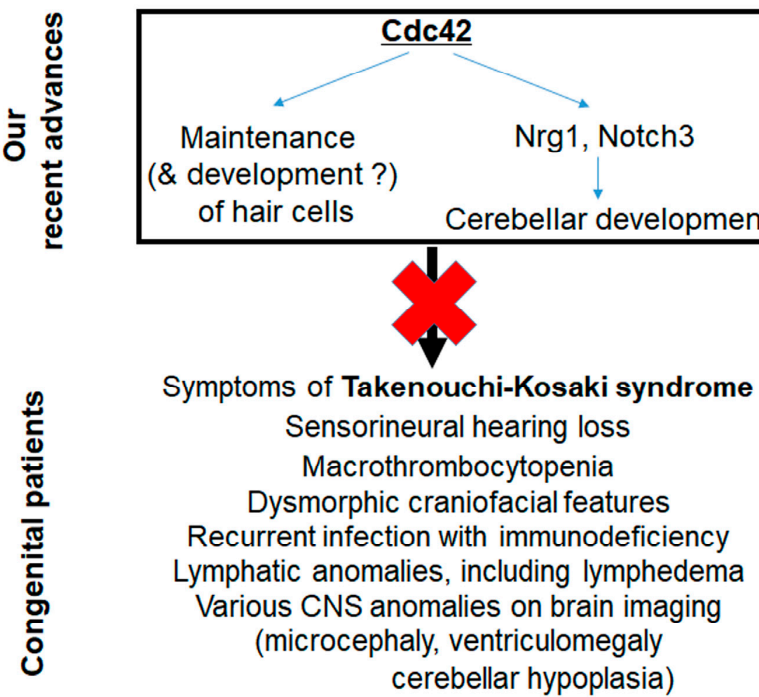

Figure 2. Functions of Rac1 (left) or Cdc42 (right) in vivo (upper), our recent advances using Rac- [66] or Cdc42-KO [57,71] mice (middle), and congenital/hereditary patients with RAC1 or CDC42 mutants (lower). Evidence from animal models helps elucidate the functions of Rac1 [66-69,72-78] and Cdc42 [71,74,79-93] and the symptoms of congenital/hereditary patients with mutations in RAC1 [20] and CDC42 [29-32]. Nrg1: neuregulin 1.

\subsection{Deafness in Patients with Active DIA1 Mutations Downstream of RhoA}

Fifteen formin proteins, which nucleate and elongate unbranched/straight actin filaments, are found in mammals and are classified into eight subfamilies [94,95]. DIA1 is one of three members 
(DIA1-DIA3) of the diaphanous-related formin (DRF) subfamily and is a downstream target of the RHOA signaling pathway [95]. DIA1 has two alternative splicing variants: DIA1-1 consists of 1263 amino acids (aa) and DIA1-2 has 1254 aa. In the latter case, in-frame exon 2 (27 nucleotide pairs; 9 aa) is skipped.

From the study of Cdc42 in cochlear HCs, we found that Cdc42 knockdown (KD) enhances RhoA signaling activation [57]. We hypothesized that the activation of DIA1 by RhoA at least partially accounts for the phenotypes observed in Cdc42-KO cochlear HCs. DIA1 is the causative gene of the first type of non-syndromic SNHL with autosomal dominant inheritance, namely, DFNA1, which was reported in 1997 [96]. However, only one Costa Rican family was reported with this defect, and the molecular mechanism of DFNA1 was not disclosed. In 2016, we reported a novel heterozygous nonsense mutation in DIA1-2 causing a constitutively active mutant of DIA1, namely, p.R1204X (p.R1213X in DIA1-1) [97]. The p.R1204X/R1213X mutation is located in the C-terminal diaphanous autoregulatory domain (DAD) and disrupts an inhibitory intramolecular interaction between the $N$-terminal diaphanous inhibitory domain (DID) and the DAD [97]. Patients with the p.R1204X mutation present with progressive SNHL, generally at high frequencies [97]. Transgenic mice with the p.R1204X mutation have a similar phenotype including progressive loss of cochlear HCs, particularly in the OHCs of the basal turn of the cochlea, progressive SNHL typically at high frequencies, various abnormal stereocilia (sparse, short, long, fused, and dislocated) of the HCs, and deformed cell-cell junctions with the SCs [97]. Other groups also reported DFNA1 caused by the constitutively active DIA1-1 mutants p.R1213X [98,99], p.R1210Serfs31X [100], p.R1210Glyfs31X [101], and E1192_Q1220del [101]. The first heterozygous mutation reported as a cause of DFNA1, p.Ala1221Valfs22X, is located outside the DAD (D1188-G1217 in DIA1-1) [96]. Nevertheless, all other mutants in DIA1 manifesting as progressive SNHL are located in the DAD and produce constitutively active DIA1 mutants. However, the molecular mechanism of the original DFNA1 mutant is still unclear.

\subsection{Macrothrombocytopenia in Patients and Mice Associated with Rho-Family GTPases}

DFNA1 is also accompanied by MTC and, occasionally, neutropenia [98,99]. Therefore, DFNA1 is a syndromic but never non-syndromic hereditary SNHL. MTC was also reported in Cdc42-KO (Figure 2), RhoA-KO, Rock2-KO, and ADF/cofilin-KO mice under the control of a megakaryocyte (MK)-specific promoter (using Pf4-Cre mice) [90,91,102-105]. The latter two mouse lines (Rock2-KO and $A D F / c o f i l i n-K O)$ have the downstream molecule $\mathrm{KO}$ in their RhoA signaling pathways. For Rac1/Cdc42-DKO (Pf4-Cre;Rac1 ${ }^{\text {flox/flox }}$;Cdc42 flox/flox $)$ mice, Rac1-KO mice showed no MTC. However, the additional deletion of Rac1 in Cdc42-KO mice markedly exacerbated their MTC phenotype [91]. The MTC in DFNA1 was explained by the reduction of proplatelet formation in cultured MKs and the increases in filamentous actin and stable microtubules in the platelets [98]. MTC in Cdc42-KO mice is theoretically compatible with that in DFNA1 because DIA1 is activated and enhanced in Cdc42-KD cells [57]. However, MTC in RhoA-KO [102], Rock2-KO [104], and ADF/cofilin-KO [103] mice contradicts our hypothesis that the activated RhoA signaling induces MTC. All patients with the CDC42 mutant p.Y64C presented with MTC even though the mutant was predicted to be active [32] (Figure 2). Non-muscle myosin heavy chain IIA (NMMHC-IIA or myosin heavy chain 9 (MYH9) encoded by the MYH9 gene) is a downstream molecule of Rock-1 and Rock-2 [106]. Patients with MYH9 mutations exhibit non-syndromic SNHL with autosomal dominant inheritance (DFNA17 (p.R705H) [107,108]) or various autosomal dominant syndromic disorders known as MYH9-related diseases (MYH9-RD). MYH9-RD (but not DFNA17) presents with MTC, which suggests that the symptoms associated with the MYH9 mutation may differ among mutation sites [109,110]. MTC was also observed in MYH9-KO (Pf4-Cre;MYH9flox/flox $)$ mice [111]. Taken together, these findings suggest that MTC is caused by disorganized (either decreased or activated) signaling in the cytoskeleton, including actin, tubulin, and myosin. 


\subsection{Deafness Associated with Rho-Family GTPases Other than Rac and Cdc42}

Other Rho-family GTPases may also be involved in hearing. Mice with RhoA deletion in the

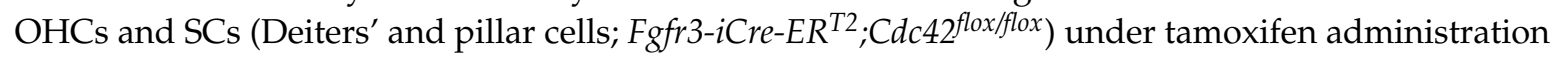
at E13 and E14 showed only mild abnormalities of the developing OHCs (enlargement of apical cell surface) and extrusion of the OHCs in the endolymph. However, the PCP of their OHCs and SCs were normal [112]. FAB65B is the causative gene of DFNB104 and binds to RhoC at the tapering stereociliary base. Conventional Fam65b-KO mice presented with hearing loss as a consequence of morphological abnormalities at the base of the stereocilia [113]. HOMER2 belongs to the homer family of post-synaptic density scaffolding proteins. It binds to CDC42 through its CDC42-binding domain (CBD) in the CC domain. Patients with a p.R185P mutation in HOMER2 showed hearing loss. Conventional Homer2 KO-mice had progressive SNHL [114]. ARHGFE6 is a specific Rho-GEF of RAC and CDC42 and one of the causative genes of $X$-linked mental retardation (XLMR). A reciprocal X/21 translocation presented with SNHL and severe intellectual disability [115]. Mice whose Arhgef6 isoform 1 was lost by genome editing had stereociliary disorganization and progressive HC loss and SNHL [116].

\subsection{Roles of Rho-Family GTPases in Other Sensory Organs}

The Rho-family GTPases may also function in other highly polarized sensory cells/organs because they participate in polarization events [45]. For example, Cdc42 is involved in the development of the outer segment and the connecting cilia of retinal photoreceptor cells, which are modified and specialized primary cilia $[79,80,117]$ (Figure 2).

\section{Host Defenses through Superoxide Generation and Arrangements of Actin and Membranes}

\subsection{Superoxide Production from Rac-Dependent Nox2-Based Oxidase}

Phagocyte NADPH oxidase (also known as gp91 ${ }^{\text {phox }}$ or Nox2) is heterodimerized with p22 phox on the membranes and activated with the support of cytosolic $\mathrm{p} 47^{\text {phox }}, \mathrm{p} 67^{\text {phox }}, \mathrm{p} 40^{\text {phox }}$, and Rac. Nox2 was the first and best characterized system identified to be under the regulation of the Rho-family GTPases [118] (Figure 1B). Nox2 activation is very tightly regulated [119-125]. Therefore, a genetic defect in any component of the Nox2 activation system results in the severe and recurrent infectious disease, chronic granulomatous disease (CGD) [123,126-129].

The first biological function ascribed to Rac was Nox2 activation [130]. The addition of either Rac1-GTP [131] or Rac2-GTP [132] was essential for high-level superoxide production in cell-free Nox2 assays. The role of Rac2 in vivo was later confirmed in hematopoietic cell-specific Rac2-KO mice [133] and the aforementioned RAC2 mutant patients $[23,24,26]$. Superoxide production from Rac1-KO neutrophils was normal [134]; however, that from DKO neutrophils of Rac1 and Rac2 had higher reducing power than that from Rac2-KO neutrophils [135]. Rac2 also participates in B lymphocyte activation and development $[26,136]$ as well as those of $\mathrm{T}$ lymphocytes $[25,26]$. DKO of Rac1 and Rac2 almost completely suppress B lymphocyte development [78].

Phagocytosis is regulated by Rac, Cdc42, RhoA, RhoB, RhoC, and RhoG via actin and membrane rearrangements [137-140]. However, only the Rac subfamily (Rac1, Rac2, and Rac3) is essential for Nox2 activation $[118,130]$. RhoG, the fourth member of the Rac subfamily, may be involved in GPCR-mediated superoxide generation from neutrophils [141]. Nevertheless, a subsequent study revealed that RhoG is neither a direct activator nor a component of Nox2-based oxidase. Rather, it regulates superoxide generation by activating a Rac-GEF, namely, Dock2 [139,142].

Translocation (targeting) of Rac from the cytosol to the phagosomal membrane (phagosome) is independent of that for the ternary phox protein complex (p47 $7^{\text {phox }}$-p67 $7^{\text {phox }}$-p40 phox $)[143,144]$. The latter is one of two cytosolic activator complexes in Nox2-based oxidase [123]. The separation of these mechanisms may account for the very tight regulation of Nox2-based oxidase. We reported the isoform-specific targeting mechanism of three Rac isoforms from the cytosol to the phagosome via their C-terminal polybasic (PB) motifs (KKRKRK in Rac1, RQQKRP in Rac2, and KKPGKK in Rac3) [120]. 
Rac1 directly targets the phagosome with the highly positively charged PB motif. In contrast, Rac2 initially targets the endomembranes which then fuse to the phagosome. Another study corroborated the delivery of Rac2 to phagosomes via the endomembranes (including granule/vesicle membranes) [145].

\subsection{Superoxide/Reactive Oxygen Species (ROS) Production from Novel Noxs}

Among the novel Nox isoforms (Nox1, Nox3, Nox4, Nox5, Duox1, and Duox2), three (Nox4, Duox1, and Duox2) are believed to provide hydrogen peroxide $\left(\mathrm{H}_{2} \mathrm{O}_{2}\right)$ rather than superoxide for signaling. The superoxide produced by these three Noxs may be very quickly converted into $\mathrm{H}_{2} \mathrm{O}_{2}$ by an unproven mechanism [146-151]. We demonstrated that Rac1 helps activate Nox1, Nox2, and Nox3 [152] (Figure 1B). We also showed that the regulation of Nox1- and Nox3-based oxidases is less strict than that of Nox2-based oxidase [123,152,153]. Other groups also reported that Rac1 directly regulates Nox1 activation [154,155].

\subsection{Regulation of Superoxide Production by RhoGDIs}

The regulatory mechanism of the cytosol-membrane cycle of the RhoGDI-Rac complex is not fully understood. This complex is one of two cytosolic Nox2-based oxidase activators. It was proposed without evidence that the Rac dissociates from RhoGDI in the cytosol. We reported that the RhoGDI $\alpha$-Rac1 and RhoGDI $\beta$-Rac1 complexes translocate/target the phagosome then Rac1 dissociates from them on the membrane [125]. Another study also reported the dissociation of Rac from RhoGDI $\beta$ on the phagosome [156]. The dissociation mechanism has been most extensively studied in phagocytosis. However, our proposal may also apply not only to phagocytosis [139,157] but to other cell types and signaling pathways as well [4]. In general, the cytosol-membrane cycle of the RhoGDI $\alpha / \beta$-RhoGTPase complex in which the RhoGTPases are activated (released from RhoGDIs and converted to GTP-bound form) on membranes may be regulated as follows: (1) interaction between the $C$-terminal PB motif in RhoGTPases and the negatively charged residues in the $N$-terminal of RhoGDI $\alpha / \beta$ to form a dimer complex in the cytosol $[120,125],(2)$ anionic phospholipids such as $\mathrm{PI}(3,4,5) \mathrm{P}_{3}, \mathrm{PA}$, and phosphatidylserine produced on membranes $[120,158,159]$ compete for binding to the PB motif in RhoGTPases with the $N$-terminal negatively charged residues in RhoGDI $\alpha / \beta$, (3) RhoGTPases are released with the help of RhoGDI dissociation factors such as GEF and phosphorylation in RhoGDI $\alpha / \beta$ [160-162], thereby promoting their membrane insertion and activation, and (4) electric repulsion between the anionic membranes and the negatively charged residues in the $N$-terminal of RhoGDI $\alpha / \beta$ promotes the dissociation of RhoGDI $\alpha / \beta$ from the membranes [125].

\section{Tumorigenesis}

\subsection{Recent Advances in Rac Involvement in Tumorigenesis}

Rac1 is well known as a tumor progression factor (Table 1) because it participates in cell migration/invasion and proliferation [163]. Nevertheless, the exact mechanisms of Rac1 in tumorigenesis have not been fully unveiled. Recently, several activating RAC mutants including RAC1 (p.P29S, p.P29T, p.N92I, pC157Y, and p.A159V) and RAC2 (p.P29L and p.P29Q) indicated that RACs are oncogenic driver genes in human melanoma and head and neck squamous cell carcinoma patients and in cancer cell lines [14,15,21,22,27]. Although these studies reveal the roles of Rac in tumorigenesis and tumor progression, the mechanism of the involvement of Rac in tumorigenesis remains obscure. Using Forster resonance energy transfer (FRET) biosensors, Hirata et al. discovered that C6 glioma cells penetrating the brain parenchyma have high Rac1 and Cdc42 activity and low RhoA activity [164]. They also found that Dock9, a GEF for Cdc42, is an upstream mediator of this invasion process [164]. It was then demonstrated that Rac1 and Cdc42 activity is variable in C6 glioma [165]. Cells with high Rac1 or Cdc42 activity invade more efficiently and have stronger invasion-inducing signaling networks than cells with low Rac1 or Cdc42 activity [165]. Rac1b is an 
alternatively spliced Rac1 isoform with a short additional exon (3b; 57 nucleotides; 29 aa). Rac1b overexpression has been reported for breast, colon, and lung cancers [166]. In mouse lung and colon tumor models, Rac1b sufficed to initiate tumorigenesis but was assisted by inflammation or K-ras mutation $[167,168]$.

\subsection{A Novel Downstream Target of Rac Signaling, GSPT1, Is Associated with Tumorigenesis}

We recently reported that the G1 phase of the primary astrocyte cell cycle is prolonged by both Rac1-KO and Rac1-KD. G1 to S phase transition 1 (GSPT1) is a novel transcriptionally regulated downstream target of Rac1 [169]. GSPT1 was initially identified as an essential gene for G1 to S phase transition in the cell cycle. However, it was later renamed as the eukaryotic releasing factor 3a (eRF3a) [170]. GSPT1/eRF3a is a GTP-binding protein participating in translation termination as a ternary complex with eRF1 and GTP. The eRF1 recognizes the terminal codon and releases the completed protein product after the hydrolysis of GTP by the intrinsic GTPase of eRF3a [170,171]. We found that Rac1-GSPT1 signaling promotes astrocyte cell cycle progression and proliferation (astrogliosis) after CNS damage such as spinal cord injury (SCI) and irradiation injury. The promotion of the G1 to S phase transition may be regulated by Rac1 via increases in cyclin D1 levels [172,173]. Genome-wide association studies (GWAS) showed that testicular germ cell tumors are susceptible to GSPT1 upregulation [174]. Xiao et al. also reported that HCT116 colorectal cancer cells express GSPT1 at high levels [175]. GSPT1 may be an antitumor drug target through ubiquitination and degradation [176]. GSPT1 may also be involved in lung and colorectal carcinoma cell migration [175,177]. In our studies, however, GSPT1 KD demonstrated no such effect in primary astrocytes, immortalized LN229 astrocytes, or A431 epidermoid carcinoma cells [169]. The reason for the discrepancy between our study and previous reports is unknown. Nevertheless, differences in the cell types and lines used may account for it. Another explanation is the difference in the cell migration assay used. A scratch assay is influenced by both cell migration and proliferation. Human GSPT1 is polymorphic and has a glycine repeat $(7,8,9,10,11$, or 12$)$ in the $N$-terminus. The most common type is the 10 repeat [178]. Several studies reported that the presence of GSPT1 with a 12 glycine repeat is correlated with increased risks of gastric, breast, and colorectal cancers [179-181]. However, the exact mechanism linking the number of glycine repeats and tumorigenesis remains unknown. The RAC1-GSPT1 signaling axis may participate in an oncogenic mechanism and is a candidate target for a novel tumor therapy.

\subsection{Involvement of Other Rho-Family GTPases in Tumorigenesis}

Other members of the Rho-family GTPases including RhoA, RhoB, RhoC, Cdc42, RhoH, and RhoBTBs may also participate in tumorigenesis (Table 1) [1,14] (Figure 1C). A mutant in RHOA, p.G17V, causes a loss of wild-type RHOA function via the loss of GTP binding capability. It was reported that p.G17V drives cancer progression in 50-70\% of all angioimmunoblastic T cell lymphoma (AITL) cases. AITL is one of the most common types of peripheral T cell lymphoma [8-10,182]. Other RHOA mutants such as p.G17del, p.G17E, p.C16R, p.T19I, p.D120Y, and p.A161E in AITL [8,9], p.R5Q (most frequent), p.Y42F, and p.Y42S in Burkitt's lymphoma were also reported [11]. Activating mutations in VAV1, a GEF of RACs and RHOs [183], were reported as oncogenic drivers of peripheral T cell lymphomas [184-187]. The RHOA mutants, p.Y42C (most frequent), p.R5Q, and p.G17E, were reported in gastric cancer [12,13]. RhoA, RhoB and RhoC have oncogenic effects [1,14]. In addition, RhoB [17,18] and RhoBTBs [5] (mainly as RhoBTB2) may suppress tumors. RhoBTBs expression was reduced or silenced in various tumor types [5]. Patients with missense mutations in RHOBTB2 presented with epilepsy, severe intellectual disability, and postnatal microcephaly [39,188]. The function of RHOBTB2 in dendritic development was verified with a Drosophila model. Research on the tumorigenesis of RHOBTB2, RAC1, RAC2, RHOA, and CDC42 mutants in human patients is ongoing. 


\section{Conclusions}

The functions of the Rho-family GTPases are gradually being elucidated, and innovative scientific and industrial applications are being developed for them. Studies using genetically engineered mice/animals (such as $\mathrm{KO}$ and knock-in) and information gathered from patients with genetic mutations are powerful tools to disclose the functions of Rho-family GTPases in vivo. Research on the Rho-family GTPases associated with sensory organs/cells involved in hearing, balance, and vision as well as those involved in various cancers, must be continued so that we gain a better understanding of the physiological role of these proteins in vivo. This will then facilitate the development of novel therapeutic modalities for sensory diseases and cancers.

Funding: The APC was funded by the Foundation for Promotion of Cancer Research in Japan.

Acknowledgments: The author thanks Naoaki Saito of Biosignal Research Center, Kobe University, Kobe, Japan, for his encouragement. The author also thanks Hirofumi Sakaguchi of Kyoto Prefectural University of Medicine, Kyoto, Japan, for critical reading of this manuscript. The author also wishes to thank the Foundation for Promotion of Cancer Research in Japan, the Naito Foundation, and the Hyogo Science and Technology Association for their support.

Conflicts of Interest: The author declares no conflict of interest. The funders had no role in the design of the study; in the collection, analyses, or interpretation of data; in the writing of the manuscript, or in the decision to publish the results.

\section{References}

1. Haga, R.B.; Ridley, A.J. Rho GTPases: Regulation and roles in cancer cell biology. Small GTPases 2016, 7, 207-221. [CrossRef] [PubMed]

2. Rossman, K.L.; Der, C.J.; Sondek, J. GEF means go: Turning on RHO GTPases with guanine nucleotide-exchange factors. Nat. Rev. Mol. Cell Biol. 2005, 6, 167-180. [CrossRef] [PubMed]

3. Goicoechea, S.M.; Awadia, S.; Garcia-Mata, R. I'm coming to GEF you: Regulation of RhoGEFs during cell migration. Cell Adh. Migr. 2014, 8, 535-549. [CrossRef] [PubMed]

4. Garcia-Mata, R.; Boulter, E.; Burridge, K. The "invisible hand": Regulation of RHO GTPases by RHOGDIs. Nat. Rev. Mol. Cell Biol. 2011, 12, 493-504. [CrossRef] [PubMed]

5. Ji, W.; Rivero, F. Atypical Rho GTPases of the RhoBTB Subfamily: Roles in Vesicle Trafficking and Tumorigenesis. Cells 2016, 5, 28. [CrossRef] [PubMed]

6. DerMardirossian, C.; Bokoch, G.M. GDIs: Central regulatory molecules in Rho GTPase activation. Trends Cell Biol. 2005, 15, 356-363. [CrossRef] [PubMed]

7. Jackson, B.; Peyrollier, K.; Pedersen, E.; Basse, A.; Karlsson, R.; Wang, Z.; Lefever, T.; Ochsenbein, A.M.; Schmidt, G.; Aktories, K.; et al. RhoA is dispensable for skin development, but crucial for contraction and directed migration of keratinocytes. Mol. Biol. Cell 2011, 22, 593-605. [CrossRef] [PubMed]

8. Palomero, T.; Couronne, L.; Khiabanian, H.; Kim, M.Y.; Ambesi-Impiombato, A.; Perez-Garcia, A.; Carpenter, Z.; Abate, F.; Allegretta, M.; Haydu, J.E.; et al. Recurrent mutations in epigenetic regulators, RHOA and FYN kinase in peripheral T cell lymphomas. Nat. Genet. 2014, 46, 166-170. [CrossRef] [PubMed]

9. Sakata-Yanagimoto, M.; Enami, T.; Yoshida, K.; Shiraishi, Y.; Ishii, R.; Miyake, Y.; Muto, H.; Tsuyama, N.; Sato-Otsubo, A.; Okuno, Y.; et al. Somatic RHOA mutation in angioimmunoblastic T cell lymphoma. Nat. Genet. 2014, 46, 171-175. [CrossRef]

10. Yoo, H.Y.; Sung, M.K.; Lee, S.H.; Kim, S.; Lee, H.; Park, S.; Kim, S.C.; Lee, B.; Rho, K.; Lee, J.E.; et al. A recurrent inactivating mutation in RHOA GTPase in angioimmunoblastic T cell lymphoma. Nat. Genet. 2014, 46, 371-375. [CrossRef]

11. Rohde, M.; Richter, J.; Schlesner, M.; Betts, M.J.; Claviez, A.; Bonn, B.R.; Zimmermann, M.; Damm-Welk, C.; Russell, R.B.; Borkhardt, A.; et al. Recurrent RHOA mutations in pediatric Burkitt lymphoma treated according to the NHL-BFM protocols. Genes Chromosomes Cancer 2014, 53, 911-916. [CrossRef] [PubMed]

12. Kakiuchi, M.; Nishizawa, T.; Ueda, H.; Gotoh, K.; Tanaka, A.; Hayashi, A.; Yamamoto, S.; Tatsuno, K.; Katoh, H.; Watanabe, Y.; et al. Recurrent gain-of-function mutations of RHOA in diffuse-type gastric carcinoma. Nat. Genet. 2014, 46, 583-587. [CrossRef] [PubMed] 
13. Wang, K.; Yuen, S.T.; Xu, J.; Lee, S.P.; Yan, H.H.; Shi, S.T.; Siu, H.C.; Deng, S.; Chu, K.M.; Law, S.; et al. Whole-genome sequencing and comprehensive molecular profiling identify new driver mutations in gastric cancer. Nat. Genet. 2014, 46, 573-582. [CrossRef] [PubMed]

14. Porter, A.P.; Papaioannou, A.; Malliri, A. Deregulation of Rho GTPases in cancer. Small GTPases 2016, 7, 123-138. [CrossRef] [PubMed]

15. Bustelo, X.R. RHO GTPases in cancer: Known facts, open questions, and therapeutic challenges. Biochem. Soc. Trans. 2018, 46, 741-760. [CrossRef] [PubMed]

16. Liu, A.X.; Rane, N.; Liu, J.P.; Prendergast, G.C. RhoB is dispensable for mouse development, but it modifies susceptibility to tumor formation as well as cell adhesion and growth factor signaling in transformed cells. Mol. Cell Biol. 2001, 21, 6906-6912. [CrossRef] [PubMed]

17. Ju, J.A.; Gilkes, D.M. RhoB: Team Oncogene or Team Tumor Suppressor? Genes (Basel) 2018, 9, 67. [CrossRef]

18. Calvayrac, O.; Nowosad, A.; Cabantous, S.; Lin, L.P.; Figarol, S.; Jeannot, P.; Serres, M.; Callot, C.; Perchey, R.T.; Creff, J.; et al. Cytoplasmic p27(Kip1) promotes tumorigenesis via suppression of RhoB activity. J. Pathol. 2018. [CrossRef]

19. Hakem, A.; Sanchez-Sweatman, O.; You-Ten, A.; Duncan, G.; Wakeham, A.; Khokha, R.; Mak, T.W. RhoC is dispensable for embryogenesis and tumor initiation but essential for metastasis. Genes. Dev. 2005, 19, 1974-1979. [CrossRef]

20. Reijnders, M.R.F.; Ansor, N.M.; Kousi, M.; Yue, W.W.; Tan, P.L.; Clarkson, K.; Clayton-Smith, J.; Corning, K.; Jones, J.R.; Lam, W.W.K.; et al. RAC1 Missense Mutations in Developmental Disorders with Diverse Phenotypes. Am. J. Hum. Genet. 2017, 101, 466-477. [CrossRef]

21. Hodis, E.; Watson, I.R.; Kryukov, G.V.; Arold, S.T.; Imielinski, M.; Theurillat, J.P.; Nickerson, E.; Auclair, D.; Li, L.; Place, C.; et al. A landscape of driver mutations in melanoma. Cell 2012, 150, 251-263. [CrossRef] [PubMed]

22. Krauthammer, M.; Kong, Y.; Ha, B.H.; Evans, P.; Bacchiocchi, A.; McCusker, J.P.; Cheng, E.; Davis, M.J.; Goh, G.; Choi, M.; et al. Exome sequencing identifies recurrent somatic RAC1 mutations in melanoma. Nat. Genet. 2012, 44, 1006-1014. [CrossRef] [PubMed]

23. Ambruso, D.R.; Knall, C.; Abell, A.N.; Panepinto, J.; Kurkchubasche, A.; Thurman, G.; Gonzalez-Aller, C.; Hiester, A.; deBoer, M.; Harbeck, R.J.; et al. Human neutrophil immunodeficiency syndrome is associated with an inhibitory Rac2 mutation. Proc. Natl. Acad Sci. USA 2000, 97, 4654-4659. [CrossRef] [PubMed]

24. Williams, D.A.; Tao, W.; Yang, F.; Kim, C.; Gu, Y.; Mansfield, P.; Levine, J.E.; Petryniak, B.; Derrow, C.W.; Harris, C.; et al. Dominant negative mutation of the hematopoietic-specific Rho GTPase, Rac2, is associated with a human phagocyte immunodeficiency. Blood 2000, 96, 1646-1654. [PubMed]

25. Accetta, D.; Syverson, G.; Bonacci, B.; Reddy, S.; Bengtson, C.; Surfus, J.; Harbeck, R.; Huttenlocher, A.; Grossman, W.; Routes, J.; et al. Human phagocyte defect caused by a Rac2 mutation detected by means of neonatal screening for T-cell lymphopenia. J. Allergy Clin. Immunol. 2011, 127, 535-538. [CrossRef] [PubMed]

26. Alkhairy, O.K.; Rezaei, N.; Graham, R.R.; Abolhassani, H.; Borte, S.; Hultenby, K.; Wu, C.; Aghamohammadi, A.; Williams, D.A.; Behrens, T.W.; et al. RAC2 loss-of-function mutation in 2 siblings with characteristics of common variable immunodeficiency. J. Allergy Clin. Immunol. 2015, 135, 1380-1384. [CrossRef] [PubMed]

27. Kawazu, M.; Ueno, T.; Kontani, K.; Ogita, Y.; Ando, M.; Fukumura, K.; Yamato, A.; Soda, M.; Takeuchi, K.; Miki, Y.; et al. Transforming mutations of RAC guanosine triphosphatases in human cancers. Proc. Natl. Acad Sci. USA 2013, 110, 3029-3034. [CrossRef] [PubMed]

28. Vigorito, E.; Bell, S.; Hebeis, B.J.; Reynolds, H.; McAdam, S.; Emson, P.C.; McKenzie, A.; Turner, M. Immunological function in mice lacking the Rac-related GTPase RhoG. Mol. Cell Biol. 2004, 24, 719-729. [CrossRef] [PubMed]

29. Takenouchi, T.; Kosaki, R.; Niizuma, T.; Hata, K.; Kosaki, K. Macrothrombocytopenia and developmental delay with a de novo CDC42 mutation: Yet another locus for thrombocytopenia and developmental delay. Am. J. Med. Genet. A 2015, 167A, 2822-2825. [CrossRef] [PubMed]

30. Takenouchi, T.; Okamoto, N.; Ida, S.; Uehara, T.; Kosaki, K. Further evidence of a mutation in CDC42 as a cause of a recognizable syndromic form of thrombocytopenia. Am. J. Med. Genet. A 2016, 170A, 852-855. [CrossRef] [PubMed] 
31. Motokawa, M.; Watanabe, S.; Nakatomi, A.; Kondoh, T.; Matsumoto, T.; Morifuji, K.; Sawada, H.; Nishimura, T.; Nunoi, H.; Yoshiura, K.I.; et al. A hot-spot mutation in CDC42 (p.Tyr64Cys) and novel phenotypes in the third patient with Takenouchi-Kosaki syndrome. J. Hum. Genet. 2018, 63, 387-390. [CrossRef] [PubMed]

32. Martinelli, S.; Krumbach, O.H.F.; Pantaleoni, F.; Coppola, S.; Amin, E.; Pannone, L.; Nouri, K.; Farina, L.; Dvorsky, R.; Lepri, F.; et al. Functional Dysregulation of CDC42 Causes Diverse Developmental Phenotypes. Am. J. Hum. Genet. 2018, 102, 309-320. [CrossRef] [PubMed]

33. Kim, C.; Yang, H.; Fukushima, Y.; Saw, P.E.; Lee, J.; Park, J.S.; Park, I.; Jung, J.; Kataoka, H.; Lee, D.; et al. Vascular RhoJ is an effective and selective target for tumor angiogenesis and vascular disruption. Cancer Cell 2014, 25, 102-117. [CrossRef]

34. Burbage, M.; Keppler, S.J.; Montaner, B.; Mattila, P.K.; Batista, F.D. The Small Rho GTPase TC10 Modulates B Cell Immune Responses. J. Immunol. 2017, 199, 1682-1695. [CrossRef] [PubMed]

35. Goggs, R.; Savage, J.S.; Mellor, H.; Poole, A.W. The small GTPase Rif is dispensable for platelet filopodia generation in mice. PLoS ONE 2013, 8, e54663. [CrossRef]

36. Gu, Y.; Chae, H.D.; Siefring, J.E.; Jasti, A.C.; Hildeman, D.A.; Williams, D.A. RhoH GTPase recruits and activates Zap70 required for T cell receptor signaling and thymocyte development. Nat. Immunol. 2006, 7 , 1182-1190. [CrossRef]

37. Preudhomme, C.; Roumier, C.; Hildebrand, M.P.; Dallery-Prudhomme, E.; Lantoine, D.; Lai, J.L.; Daudignon, A.; Adenis, C.; Bauters, F.; Fenaux, P.; et al. Nonrandom 4p13 rearrangements of the RhoH/TTF gene, encoding a GTP-binding protein, in non-Hodgkin's lymphoma and multiple myeloma. Oncogene 2000, 19, 2023-2032. [CrossRef] [PubMed]

38. Pasqualucci, L.; Neumeister, P.; Goossens, T.; Nanjangud, G.; Chaganti, R.S.K.; Küppers, R.; Dalla-Favera, R. Hypermutation of multiple proto-oncogenes in B-cell diffuse large-cell lymphomas. Nature 2001, 412, 341-346. [CrossRef] [PubMed]

39. Straub, J.; Konrad, E.D.H.; Gruner, J.; Toutain, A.; Bok, L.A.; Cho, M.T.; Crawford, H.P.; Dubbs, H.; Douglas, G.; Jobling, R.; et al. Missense Variants in RHOBTB2 Cause a Developmental and Epileptic Encephalopathy in Humans, and Altered Levels Cause Neurological Defects in Drosophila. Am. J. Hum. Genet. 2018, 102, 44-57. [CrossRef] [PubMed]

40. Lutz, J.; Grimm-Gunter, E.M.; Joshi, P.; Rivero, F. Expression analysis of mouse Rhobtb3 using a LacZ reporter and preliminary characterization of a knockout strain. Histochem. Cell Biol. 2014, 142, 511-528. [CrossRef] [PubMed]

41. Heasman, S.J.; Ridley, A.J. Mammalian Rho GTPases: New insights into their functions from in vivo studies. Nat. Rev. Mol. Cell Biol. 2008, 9, 690-701. [CrossRef] [PubMed]

42. Bosco, E.E.; Mulloy, J.C.; Zheng, Y. Rac1 GTPase: A “Rac” of all trades. Cell Mol. Life Sci. 2009, 66, 370-374. [CrossRef]

43. Funahashi, Y.; Namba, T.; Nakamuta, S.; Kaibuchi, K. Neuronal polarization in vivo: Growing in a complex environment. Curr. Opin. Neurobiol. 2014, 27, 215-223. [CrossRef] [PubMed]

44. Chircop, M. Rho GTPases as regulators of mitosis and cytokinesis in mammalian cells. Small GTPases 2014, 5, 14. [CrossRef] [PubMed]

45. Mack, N.A.; Georgiou, M. The interdependence of the Rho GTPases and apicobasal cell polarity. Small GTPases 2014, 5, 10. [CrossRef] [PubMed]

46. Michalski, N.; Petit, C. Genetics of auditory mechano-electrical transduction. Pflugers Arch. 2015, 467, 49-72. [CrossRef] [PubMed]

47. McGrath, J.; Roy, P.; Perrin, B.J. Stereocilia morphogenesis and maintenance through regulation of actin stability. Semin Cell Dev. Biol. 2017, 65, 88-95. [CrossRef]

48. Goutman, J.D.; Elgoyhen, A.B.; Gomez-Casati, M.E. Cochlear hair cells: The sound-sensing machines. FEBS Lett. 2015, 589, 3354-3361. [CrossRef]

49. Pollock, L.M.; McDermott, B.M., Jr. The cuticular plate: A riddle, wrapped in a mystery, inside a hair cell. Birth Defects Res. C Embryo Today 2015, 105, 126-139. [CrossRef] [PubMed]

50. Grimsley-Myers, C.M.; Sipe, C.W.; Geleoc, G.S.; Lu, X. The small GTPase Rac1 regulates auditory hair cell morphogenesis. J. Neurosci. 2009, 29, 15859-15869. [CrossRef] [PubMed]

51. Grimsley-Myers, C.M.; Sipe, C.W.; Wu, D.K.; Lu, X. Redundant functions of Rac GTPases in inner ear morphogenesis. Dev. Biol. 2012, 362, 172-186. [CrossRef] [PubMed] 
52. Hebert, J.M.; McConnell, S.K. Targeting of cre to the Foxg1 (BF-1) locus mediates loxP recombination in the telencephalon and other developing head structures. Dev. Biol. 2000, 222, 296-306. [CrossRef] [PubMed]

53. Pirvola, U.; Ylikoski, J.; Trokovic, R.; Hebert, J.M.; McConnell, S.K.; Partanen, J. FGFR1 is required for the development of the auditory sensory epithelium. Neuron 2002, 35, 671-680. [CrossRef]

54. Ohyama, T.; Groves, A.K. Generation of Pax2-Cre mice by modification of a Pax2 bacterial artificial chromosome. Genesis 2004, 38, 195-199. [CrossRef] [PubMed]

55. Kelley, M.W. Regulation of cell fate in the sensory epithelia of the inner ear. Nat. Rev. Neurosci. 2006, 7, 837-849. [CrossRef] [PubMed]

56. Cox, B.C.; Liu, Z.; Lagarde, M.M.; Zuo, J. Conditional gene expression in the mouse inner ear using Cre-loxP. J. Assoc. Res. Otolaryngol. 2012, 13, 295-322. [CrossRef]

57. Ueyama, T.; Sakaguchi, H.; Nakamura, T.; Goto, A.; Morioka, S.; Shimizu, A.; Nakao, K.; Hishikawa, Y.; Ninoyu, Y.; Kassai, H.; et al. Maintenance of stereocilia and apical junctional complexes by Cdc42 in cochlear hair cells. J. Cell Sci. 2014, 127, 2040-2052. [CrossRef]

58. Zhang, D.S.; Piazza, V.; Perrin, B.J.; Rzadzinska, A.K.; Poczatek, J.C.; Wang, M.; Prosser, H.M.; Ervasti, J.M.; Corey, D.P.; Lechene, C.P. Multi-isotope imaging mass spectrometry reveals slow protein turnover in hair-cell stereocilia. Nature 2012, 481, 520-524. [CrossRef]

59. Narayanan, P.; Chatterton, P.; Ikeda, A.; Ikeda, S.; Corey, D.P.; Ervasti, J.M.; Perrin, B.J. Length regulation of mechanosensitive stereocilia depends on very slow actin dynamics and filament-severing proteins. Nat. Commun. 2015, 6, 6855. [CrossRef]

60. Drummond, M.C.; Barzik, M.; Bird, J.E.; Zhang, D.S.; Lechene, C.P.; Corey, D.P.; Cunningham, L.L.; Friedman, T.B. Live-cell imaging of actin dynamics reveals mechanisms of stereocilia length regulation in the inner ear. Nat. Commun. 2015, 6, 6873. [CrossRef]

61. Scheffer, D.I.; Shen, J.; Corey, D.P.; Chen, Z.Y. Gene Expression by Mouse Inner Ear Hair Cells during Development. J. Neurosci. 2015, 35, 6366-6380. [CrossRef] [PubMed]

62. Anttonen, T.; Kirjavainen, A.; Belevich, I.; Laos, M.; Richardson, W.D.; Jokitalo, E.; Brakebusch, C.; Pirvola, U. Cdc42-dependent structural development of auditory supporting cells is required for wound healing at adulthood. Sci. Rep. 2012, 2, 978. [CrossRef] [PubMed]

63. Kirjavainen, A.; Laos, M.; Anttonen, T.; Pirvola, U. The Rho GTPase Cdc42 regulates hair cell planar polarity and cellular patterning in the developing cochlea. Biol. Open 2015, 4, 516-526. [CrossRef] [PubMed]

64. Matei, V.; Pauley, S.; Kaing, S.; Rowitch, D.; Beisel, K.W.; Morris, K.; Feng, F.; Jones, K.; Lee, J.; Fritzsch, B. Smaller inner ear sensory epithelia in Neurog 1 null mice are related to earlier hair cell cycle exit. Dev. Dyn. 2005, 234, 633-650. [CrossRef] [PubMed]

65. Yang, H.; Xie, X.; Deng, M.; Chen, X.; Gan, L. Generation and characterization of Atoh1-Cre knock-in mouse line. Genesis 2010, 48, 407-413. [CrossRef]

66. Nakamura, T.; Ueyama, T.; Ninoyu, Y.; Sakaguchi, H.; Choijookhuu, N.; Hishikawa, Y.; Kiyonari, H.; Kohta, M.; Sakahara, M.; de Curtis, I.; et al. Novel role of Rac-Mid1 signaling in medial cerebellar development. Development 2017, 144, 1863-1875. [CrossRef] [PubMed]

67. Tahirovic, S.; Hellal, F.; Neukirchen, D.; Hindges, R.; Garvalov, B.K.; Flynn, K.C.; Stradal, T.E.; Chrostek-Grashoff, A.; Brakebusch, C.; Bradke, F. Rac1 regulates neuronal polarization through the WAVE complex. J. Neurosci. 2010, 30, 6930-6943. [CrossRef] [PubMed]

68. Chen, L.; Liao, G.; Waclaw, R.R.; Burns, K.A.; Linquist, D.; Campbell, K.; Zheng, Y.; Kuan, C.Y. Rac1 controls the formation of midline commissures and the competency of tangential migration in ventral telencephalic neurons. J. Neurosci. 2007, 27, 3884-3893. [CrossRef]

69. Kassai, H.; Terashima, T.; Fukaya, M.; Nakao, K.; Sakahara, M.; Watanabe, M.; Aiba, A. Rac1 in cortical projection neurons is selectively required for midline crossing of commissural axonal formation. Eur. J. Neurosci. 2008, 28, 257-267. [CrossRef]

70. Chen, L.; Melendez, J.; Campbell, K.; Kuan, C.Y.; Zheng, Y. Rac1 deficiency in the forebrain results in neural progenitor reduction and microcephaly. Dev. Biol. 2009, 325, 162-170. [CrossRef]

71. Sakamoto, I.; Ueyama, T.; Hayashibe, M.; Nakamura, T.; Mohri, H.; Kiyonari, H.; Shigyo, M.; Tohda, C.; Saito, N. Roles of Cdc42 and Rac in Bergmann glia during cerebellar corticogenesis. Exp. Neurol. 2018, 302, 57-67. [CrossRef] [PubMed] 
72. Pennucci, R.; Talpo, F.; Astro, V.; Montinaro, V.; More, L.; Cursi, M.; Castoldi, V.; Chiaretti, S.; Bianchi, V.; Marenna, S.; et al. Loss of Either Rac1 or Rac3 GTPase Differentially Affects the Behavior of Mutant Mice and the Development of Functional GABAergic Networks. Cereb. Cortex. 2016, 26, 873-890. [CrossRef] [PubMed]

73. Croke, M.; Ross, F.P.; Korhonen, M.; Williams, D.A.; Zou, W.; Teitelbaum, S.L. Rac deletion in osteoclasts causes severe osteopetrosis. J. Cell Sci. 2011, 124, 3811-3821. [CrossRef] [PubMed]

74. Touaitahuata, H.; Blangy, A.; Vives, V. Modulation of osteoclast differentiation and bone resorption by Rho GTPases. Small GTPases 2014, 5, e28119. [CrossRef] [PubMed]

75. Benitah, S.A.; Frye, M.; Glogauer, M.; Watt, F.M. Stem cell depletion through epidermal deletion of Rac1. Science 2005, 309, 933-935. [CrossRef] [PubMed]

76. Chrostek, A.; Wu, X.; Quondamatteo, F.; Hu, R.; Sanecka, A.; Niemann, C.; Langbein, L.; Haase, I.; Brakebusch, C. Rac1 is crucial for hair follicle integrity but is not essential for maintenance of the epidermis. Mol. Cell Biol 2006, 26, 6957-6970. [CrossRef] [PubMed]

77. Castilho, R.M.; Squarize, C.H.; Patel, V.; Millar, S.E.; Zheng, Y.; Molinolo, A.; Gutkind, J.S. Requirement of Rac1 distinguishes follicular from interfollicular epithelial stem cells. Oncogene 2007, 26, 5078-5085. [CrossRef]

78. Walmsley, M.J.; Ooi, S.K.; Reynolds, L.F.; Smith, S.H.; Ruf, S.; Mathiot, A.; Vanes, L.; Williams, D.A.; Cancro, M.P.; Tybulewicz, V.L. Critical roles for Rac1 and Rac2 GTPases in B cell development and signaling. Science 2003, 302, 459-462. [CrossRef]

79. Choi, S.Y.; Chacon-Heszele, M.F.; Huang, L.; McKenna, S.; Wilson, F.P.; Zuo, X.; Lipschutz, J.H. Cdc42 deficiency causes ciliary abnormalities and cystic kidneys. J. Am. Soc. Nephrol. 2013, 24, 1435-1450. [CrossRef]

80. Choi, S.Y.; Baek, J.I.; Zuo, X.; Kim, S.H.; Dunaief, J.L.; Lipschutz, J.H. Cdc42 and sec10 Are Required for Normal Retinal Development in Zebrafish. Invest. Ophthalmol. Vis. Sci. 2015, 56, 3361-3370. [CrossRef]

81. Cappello, S.; Attardo, A.; Wu, X.; Iwasato, T.; Itohara, S.; Wilsch-Brauninger, M.; Eilken, H.M.; Rieger, M.A.; Schroeder, T.T.; Huttner, W.B.; et al. The Rho-GTPase cdc42 regulates neural progenitor fate at the apical surface. Nat. Neurosci. 2006, 9, 1099-1107. [CrossRef] [PubMed]

82. Chen, L.; Liao, G.; Yang, L.; Campbell, K.; Nakafuku, M.; Kuan, C.Y.; Zheng, Y. Cdc42 deficiency causes Sonic hedgehog-independent holoprosencephaly. PNAS 2006, 103, 16520-16525. [CrossRef] [PubMed]

83. Ito, Y.; Teitelbaum, S.L.; Zou, W.; Zheng, Y.; Johnson, J.F.; Chappel, J.; Ross, F.P.; Zhao, H. Cdc42 regulates bone modeling and remodeling in mice by modulating RANKL/M-CSF signaling and osteoclast polarization. J. Clin. Invest. 2010, 120, 1981-1993. [CrossRef] [PubMed]

84. Aizawa, R.; Yamada, A.; Suzuki, D.; Iimura, T.; Kassai, H.; Harada, T.; Tsukasaki, M.; Yamamoto, G.; Tachikawa, T.; Nakao, K.; et al. Cdc42 is required for chondrogenesis and interdigital programmed cell death during limb development. Mech. Dev. 2012, 129, 38-50. [CrossRef] [PubMed]

85. Oshima-Nakayama, M.; Yamada, A.; Kurosawa, T.; Aizawa, R.; Suzuki, D.; Saito, Y.; Kassai, H.; Sato, Y.; Yamamoto, M.; Shirota, T.; et al. Cdc42 is crucial for facial and palatal formation during craniofacial development. Bone Rep. 2016, 5, 1-6. [CrossRef] [PubMed]

86. Wu, X.; Quondamatteo, F.; Lefever, T.; Czuchra, A.; Meyer, H.; Chrostek, A.; Paus, R.; Langbein, L.; Brakebusch, C. Cdc42 controls progenitor cell differentiation and beta-catenin turnover in skin. Genes Dev. 2006, 20, 571-585. [CrossRef]

87. Guo, F.; Velu, C.S.; Grimes, H.L.; Zheng, Y. Rho GTPase Cdc42 is essential for B-lymphocyte development and activation. Blood 2009, 114, 2909-2916. [CrossRef] [PubMed]

88. Guo, F.; Hildeman, D.; Tripathi, P.; Velu, C.S.; Grimes, H.L.; Zheng, Y. Coordination of IL-7 receptor and T-cell receptor signaling by cell-division cycle 42 in T-cell homeostasis. Proc. Natl. Acad Sci. USA 2010, 107, 18505-18510. [CrossRef] [PubMed]

89. Melendez, J.; Grogg, M.; Zheng, Y. Signaling role of Cdc42 in regulating mammalian physiology. J. Biol. Chem. 2011, 286, 2375-2381. [CrossRef] [PubMed]

90. Pleines, I.; Eckly, A.; Elvers, M.; Hagedorn, I.; Eliautou, S.; Bender, M.; Wu, X.; Lanza, F.; Gachet, C.; Brakebusch, C.; et al. Multiple alterations of platelet functions dominated by increased secretion in mice lacking Cdc42 in platelets. Blood 2010, 115, 3364-3373. [CrossRef] [PubMed]

91. Pleines, I.; Dutting, S.; Cherpokova, D.; Eckly, A.; Meyer, I.; Morowski, M.; Krohne, G.; Schulze, H.; Gachet, C.; Debili, N.; et al. Defective tubulin organization and proplatelet formation in murine megakaryocytes lacking Rac1 and Cdc42. Blood 2013, 122, 3178-3187. [CrossRef] [PubMed] 
92. Wakayama, Y.; Fukuhara, S.; Ando, K.; Matsuda, M.; Mochizuki, N. Cdc42 mediates Bmp-induced sprouting angiogenesis through Fmnl3-driven assembly of endothelial filopodia in zebrafish. Dev. Cell 2015, 32, 109-122. [CrossRef] [PubMed]

93. Liu, X.; Gu, X.; Ma, W.; Oxendine, M.; Gil, H.J.; Davis, G.E.; Cleaver, O.; Oliver, G. Rasip1 controls lymphatic vessel lumen maintenance by regulating endothelial cell junctions. Development 2018, 145. [CrossRef] [PubMed]

94. Campellone, K.G.; Welch, M.D. A nucleator arms race: Cellular control of actin assembly. Nat. Rev. Mol. Cell Biol. 2010, 11, 237-251. [CrossRef] [PubMed]

95. Kuhn, S.; Geyer, M. Formins as effector proteins of Rho GTPases. Small GTPases 2014, 5, e29513. [CrossRef] [PubMed]

96. Lynch, E.D.; Lee, M.K.; Morrow, J.E.; Welcsh, P.L.; Leon, P.E.; King, M.C. Nonsyndromic deafness DFNA1 associated with mutation of a human homolog of the Drosophila gene diaphanous. Science 1997, 278, 1315-1318. [CrossRef] [PubMed]

97. Ueyama, T.; Ninoyu, Y.; Nishio, S.Y.; Miyoshi, T.; Torii, H.; Nishimura, K.; Sugahara, K.; Sakata, H.; Thumkeo, D.; Sakaguchi, H.; et al. Constitutive activation of DIA1 (DIAPH1) via C-terminal truncation causes human sensorineural hearing loss. EMBO Mol. Med. 2016, 8, 1310-1324. [CrossRef] [PubMed]

98. Stritt, S.; Nurden, P.; Turro, E.; Greene, D.; Jansen, S.B.; Westbury, S.K.; Petersen, R.; Astle, W.J.; Marlin, S.; Bariana, T.K.; et al. A gain-of-function variant in DIAPH1 causes dominant macrothrombocytopenia and hearing loss. Blood 2016, 127, 2903-2914. [CrossRef]

99. Ganaha, A.; Kaname, T.; Shinjou, A.; Chinen, Y.; Yanagi, K.; Higa, T.; Kondo, S.; Suzuki, M. Progressive macrothrombocytopenia and hearing loss in a large family with DIAPH1 related disease. Am. J. Med. Genet. A 2017, 173, 2826-2830. [CrossRef]

100. Neuhaus, C.; Lang-Roth, R.; Zimmermann, U.; Heller, R.; Eisenberger, T.; Weikert, M.; Markus, S.; Knipper, M.; Bolz, H.J. Extension of the clinical and molecular phenotype of DIAPH1-associated autosomal dominant hearing loss (DFNA1). Clin. Genet. 2016, 91, 892-901. [CrossRef]

101. Westbury, S.K.; Downes, K.; Burney, C.; Lozano, M.L.; Obaji, S.G.; Toh, C.H.; Sevivas, T.; Morgan, N.V.; Erber, W.N.; Kempster, C.; et al. Phenotype description and response to thrombopoietin receptor agonist in DIAPH1-related disorder. Blood Adv. 2018, 2, 2341-2346. [CrossRef]

102. Pleines, I.; Hagedorn, I.; Gupta, S.; May, F.; Chakarova, L.; van Hengel, J.; Offermanns, S.; Krohne, G.; Kleinschnitz, C.; Brakebusch, C.; et al. Megakaryocyte-specific RhoA deficiency causes macrothrombocytopenia and defective platelet activation in hemostasis and thrombosis. Blood 2012, 119, 1054-1063. [CrossRef] [PubMed]

103. Bender, M.; Eckly, A.; Hartwig, J.H.; Elvers, M.; Pleines, I.; Gupta, S.; Krohne, G.; Jeanclos, E.; Gohla, A.; Gurniak, C.; et al. ADF/n-cofilin-dependent actin turnover determines platelet formation and sizing. Blood 2010, 116, 1767-1775. [CrossRef] [PubMed]

104. Sladojevic, N.; Oh, G.T.; Kim, H.H.; Beaulieu, L.M.; Falet, H.; Kaminski, K.; Freedman, J.E.; Liao, J.K. Decreased thromboembolic stroke but not atherosclerosis or vascular remodelling in mice with ROCK2-deficient platelets. Cardiovasc. Res. 2017, 113, 1307-1317. [CrossRef] [PubMed]

105. Pleines, I.; Cherpokova, D.; Bender, M. Rho GTPases and their downstream effectors in megakaryocyte biology. Platelets 2018, 1-8. [CrossRef] [PubMed]

106. Narumiya, S.; Thumkeo, D. Rho signaling research: History, current status and future directions. FEBS Lett. 2018, 592, 1763-1776. [CrossRef] [PubMed]

107. Lalwani, A.K.; Luxford, W.M.; Mhatre, A.N.; Attaie, A.; Wilcox, E.R.; Castelein, C.M. A new locus for nonsyndromic hereditary hearing impairment, DFNA17, maps to chromosome 22 and represents a gene for cochleosaccular degeneration. Am. J. Hum. Genet. 1999, 64, 318-323. [CrossRef] [PubMed]

108. Lalwani, A.K.; Goldstein, J.A.; Kelley, M.J.; Luxford, W.; Castelein, C.M.; Mhatre, A.N. Human nonsyndromic hereditary deafness DFNA17 is due to a mutation in nonmuscle myosin MYH9. Am. J. Hum. Genet. 2000, 67, 1121-1128. [CrossRef] [PubMed]

109. Heath, K.E.; Campos-Barros, A.; Toren, A.; Rozenfeld-Granot, G.; Carlsson, L.E.; Savige, J.; Denison, J.C.; Gregory, M.C.; White, J.G.; Barker, D.F.; et al. Nonmuscle myosin heavy chain IIA mutations define a spectrum of autosomal dominant macrothrombocytopenias: May-Hegglin anomaly and Fechtner, Sebastian, Epstein, and Alport-like syndromes. Am. J. Hum. Genet. 2001, 69, 1033-1045. [CrossRef] 
110. Balduini, C.L.; Pecci, A.; Savoia, A. Recent advances in the understanding and management of MYH9-related inherited thrombocytopenias. Br. J. Haematol. 2011, 154, 161-174. [CrossRef]

111. Leon, C.; Eckly, A.; Hechler, B.; Aleil, B.; Freund, M.; Ravanat, C.; Jourdain, M.; Nonne, C.; Weber, J.; Tiedt, R.; et al. Megakaryocyte-restricted MYH9 inactivation dramatically affects hemostasis while preserving platelet aggregation and secretion. Blood 2007, 110, 3183-3191. [CrossRef] [PubMed]

112. Anttonen, T.; Belevich, I.; Laos, M.; Herranen, A.; Jokitalo, E.; Brakebusch, C.; Pirvola, U. Cytoskeletal Stability in the Auditory Organ In Vivo: RhoA Is Dispensable for Wound Healing but Essential for Hair Cell Development. eNeuro 2017, 4, ENEURO-0149. [CrossRef] [PubMed]

113. Zhao, B.; Wu, Z.; Muller, U. Murine Fam65b forms ring-like structures at the base of stereocilia critical for mechanosensory hair cell function. Elife 2016, 5, e14222. [CrossRef] [PubMed]

114. Azaiez, H.; Decker, A.R.; Booth, K.T.; Simpson, A.C.; Shearer, A.E.; Huygen, P.L.; Bu, F.; Hildebrand, M.S.; Ranum, P.T.; Shibata, S.B.; et al. HOMER2, a stereociliary scaffolding protein, is essential for normal hearing in humans and mice. PLoS Genet. 2015, 11, e1005137. [CrossRef]

115. Kutsche, K.; Yntema, H.; Brandt, A.; Jantke, I.; Nothwang, H.G.; Orth, U.; Boavida, M.G.; David, D.; Chelly, J.; Fryns, J.P.; et al. Mutations in ARHGEF6, encoding a guanine nucleotide exchange factor for Rho GTPases, in patients with X-linked mental retardation. Nat. Genet. 2000, 26, 247-250. [CrossRef]

116. Zhu, C.; Cheng, C.; Wang, Y.; Muhammad, W.; Liu, S.; Zhu, W.; Shao, B.; Zhang, Z.; Yan, X.; He, Q.; et al. Loss of ARHGEF6 Causes Hair Cell Stereocilia Deficits and Hearing Loss in Mice. Front. Mol. Neurosci 2018, 11, 362. [CrossRef]

117. Khanna, H. Photoreceptor Sensory Cilium: Traversing the Ciliary Gate. Cells 2015, 4, 674-686. [CrossRef]

118. Bokoch, G.M.; Diebold, B.A. Current molecular models for NADPH oxidase regulation by Rac GTPase. Blood 2002, 100, 2692-2696. [CrossRef]

119. Ueyama, T.; Lennartz, M.R.; Noda, Y.; Kobayashi, T.; Shirai, Y.; Rikitake, K.; Yamasaki, T.; Hayashi, S.; Sakai, N.; Seguchi, H.; et al. Superoxide production at phagosomal cup/phagosome through $\beta I$ protein kinase C during Fc $\gamma$ R-mediated phagocytosis in microglia. J. Immunol. 2004, 173, 4582-4589. [CrossRef]

120. Ueyama, T.; Eto, M.; Kami, K.; Tatsuno, T.; Kobayashi, T.; Shirai, Y.; Lennartz, M.R.; Takeya, R.; Sumimoto, H.; Saito, N. Isoform-specific membrane targeting mechanism of Rac during Fc $\gamma$ R-mediated phagocytosis: Positive charge-dependent and independent targeting mechanism of Rac to the phagosome. J. Immunol. 2005, 175, 2381-2390. [CrossRef]

121. Ueyama, T.; Tatsuno, T.; Kawasaki, T.; Tsujibe, S.; Shirai, Y.; Sumimoto, H.; Leto, T.L.; Saito, N. A regulated adaptor function of $\mathrm{p} 40^{\text {phox }}$ : Distinct $\mathrm{p} 67^{\text {phox }}$ membrane targeting by $\mathrm{p} 40^{\text {phox }}$ and by $\mathrm{p} 47^{\text {phox }}$. Mol. Biol. Cell 2007, 18, 441-454. [CrossRef] [PubMed]

122. Ueyama, T.; Kusakabe, T.; Karasawa, S.; Kawasaki, T.; Shimizu, A.; Son, J.; Leto, T.L.; Miyawaki, A.; Saito, N. Sequential binding of cytosolic Phox complex to phagosomes through regulated adaptor proteins: Evaluation using the novel monomeric Kusabira-Green System and live imaging of phagocytosis. J. Immunol. 2008, 181, 629-640. [CrossRef] [PubMed]

123. Leto, T.L.; Morand, S.; Hurt, D.; Ueyama, T. Targeting and Regulation of Reactive Oxygen Species Generation by Nox Family NADPH Oxidases. Antioxid. Redox. Signal. 2009, 11, 2607-2619. [CrossRef] [PubMed]

124. Ueyama, T.; Nakakita, J.; Nakamura, T.; Kobayashi, T.; Son, J.; Sakuma, M.; Sakaguchi, H.; Leto, T.L.; Saito, N. Cooperation of $\mathrm{p} 40^{\text {phox }}$ with $\mathrm{p} 47^{\text {phox }}$ for Nox2-based NADPH oxidase activation during Fc $\gamma$ R-mediated phagocytosis: Mechanism for acquisition of p40 phox PI(3)P binding. J. Biol. Chem. 2011, 286, 40693-40705. [CrossRef] [PubMed]

125. Ueyama, T.; Son, J.; Kobayashi, T.; Hamada, T.; Nakamura, T.; Sakaguchi, H.; Shirafuji, T.; Saito, N. Negative Charges in the Flexible N-Terminal Domain of Rho GDP-Dissociation Inhibitors (RhoGDIs) Regulate the Targeting of the RhoGDI-Rac1 Complex to Membranes. J. Immunol. 2013, 191, 2560-2569. [CrossRef]

126. Roos, D.; Kuhns, D.B.; Maddalena, A.; Bustamante, J.; Kannengiesser, C.; de Boer, M.; van Leeuwen, K.; Koker, M.Y.; Wolach, B.; Roesler, J.; et al. Hematologically important mutations: The autosomal recessive forms of chronic granulomatous disease (second update). Blood Cells Mol. Dis. 2010, 44, 291-299. [CrossRef]

127. Roos, D.; Kuhns, D.B.; Maddalena, A.; Roesler, J.; Lopez, J.A.; Ariga, T.; Avcin, T.; de Boer, M.; Bustamante, J.; Condino-Neto, A.; et al. Hematologically important mutations: X-linked chronic granulomatous disease (third update). Blood Cells Mol. Dis. 2010, 45, 246-265. [CrossRef]

128. Nunes, P.; Demaurex, N.; Dinauer, M.C. Regulation of the NADPH oxidase and associated ion fluxes during phagocytosis. Traffic 2013, 14, 1118-1131. [CrossRef] 
129. Brandes, R.P.; Weissmann, N.; Schroder, K. Nox family NADPH oxidases: Molecular mechanisms of activation. Free Radic Biol. Med. 2014, 76, 208-226. [CrossRef]

130. Dinauer, M.C. Regulation of neutrophil function by Rac GTPases. Curr. Opin. Hematol. 2003, 10, 8-15. [CrossRef]

131. Abo, A.; Pick, E.; Hall, A.; Totty, N.; Teahan, C.G.; Segal, A.W. Activation of the NADPH oxidase involves the small GTP-binding protein p21rac1. Nature 1991, 353, 668-670. [CrossRef] [PubMed]

132. Knaus, U.G.; Heyworth, P.G.; Evans, T.; Curnutte, J.T.; Bokoch, G.M. Regulation of phagocyte oxygen radical production by the GTP-binding protein Rac 2. Science 1991, 254, 1512-1515. [CrossRef] [PubMed]

133. Roberts, A.W.; Kim, C.; Zhen, L.; Lowe, J.B.; Kapur, R.; Petryniak, B.; Spaetti, A.; Pollock, J.D.; Borneo, J.B.; Bradford, G.B.; et al. Deficiency of the hematopoietic cell-specific Rho family GTPase Rac2 is characterized by abnormalities in neutrophil function and host defense. Immunity 1999, 10, 183-196. [CrossRef]

134. Glogauer, M.; Marchal, C.C.; Zhu, F.; Worku, A.; Clausen, B.E.; Foerster, I.; Marks, P.; Downey, G.P.; Dinauer, M.; Kwiatkowski, D.J. Rac1 deletion in mouse neutrophils has selective effects on neutrophil functions. J. Immunol. 2003, 170, 5652-5657. [CrossRef]

135. Gu, Y.; Filippi, M.D.; Cancelas, J.A.; Siefring, J.E.; Williams, E.P.; Jasti, A.C.; Harris, C.E.; Lee, A.W.; Prabhakar, R.; Atkinson, S.J.; et al. Hematopoietic cell regulation by Rac1 and Rac2 guanosine triphosphatases. Science 2003, 302, 445-449. [CrossRef] [PubMed]

136. Croker, B.A.; Tarlinton, D.M.; Cluse, L.A.; Tuxen, A.J.; Light, A.; Yang, F.C.; Williams, D.A.; Roberts, A.W. The Rac2 guanosine triphosphatase regulates $B$ lymphocyte antigen receptor responses and chemotaxis and is required for establishment of B-1a and marginal zone B lymphocytes. J. Immunol. 2002, 168, 3376-3386. [CrossRef]

137. Hoppe, A.D.; Swanson, J.A. Cdc42, Rac1, and Rac2 display distinct patterns of activation during phagocytosis. Mol. Biol. Cell 2004, 15, 3509-3519. [CrossRef]

138. Zhang, J.; Zhu, J.; Bu, X.; Cushion, M.; Kinane, T.B.; Avraham, H.; Koziel, H. Cdc42 and RhoB activation are required for mannose receptor-mediated phagocytosis by human alveolar macrophages. Mol. Biol. Cell 2005, 16, 824-834. [CrossRef] [PubMed]

139. Mao, Y.; Finnemann, S.C. Regulation of phagocytosis by Rho GTPases. Small GTPases 2015, 6, 89-99. [CrossRef] [PubMed]

140. Egami, Y.; Kawai, K.; Araki, N. RhoC regulates the actin remodeling required for phagosome formation during FcgammaR-mediated phagocytosis. J. Cell Sci. 2017, 130, 4168-4179. [CrossRef]

141. Condliffe, A.M.; Webb, L.M.; Ferguson, G.J.; Davidson, K.; Turner, M.; Vigorito, E.; Manifava, M.; Chilvers, E.R.; Stephens, L.R.; Hawkins, P.T. RhoG regulates the neutrophil NADPH oxidase. J. Immunol. 2006, 176, 5314-5320. [CrossRef] [PubMed]

142. Damoulakis, G.; Gambardella, L.; Rossman, K.L.; Lawson, C.D.; Anderson, K.E.; Fukui, Y.; Welch, H.C.; Der, C.J.; Stephens, L.R.; Hawkins, P.T. P-Rex1 directly activates RhoG to regulate GPCR-driven Rac signalling and actin polarity in neutrophils. J. Cell Sci. 2014, 127, 2589-2600. [CrossRef] [PubMed]

143. Heyworth, P.; Bohl, B.; Bokoch, G.; Curnutte, J. Rac translocates independently of the neutrophil NADPH oxidase components p47 ${ }^{\text {hox }}$ and p67 ${ }^{\text {phox }}$. J. Biol. Chem. 1994, 269, 30749-30752. [PubMed]

144. Kim, C.; Dinauer, M.C. Impaired NADPH oxidase activity in Rac2-deficient murine neutrophils does not result from defective translocation of $\mathrm{p} 47 \mathrm{phox}$ and $\mathrm{p} 67 \mathrm{phox}$ and can be rescued by exogenous arachidonic acid. J. Leukoc. Biol. 2006, 79, 223-234. [CrossRef] [PubMed]

145. Anderson, K.E.; Chessa, T.A.; Davidson, K.; Henderson, R.B.; Walker, S.; Tolmachova, T.; Grys, K.; Rausch, O.; Seabra, M.C.; Tybulewicz, V.L.; et al. PtdIns3P and Rac direct the assembly of the NADPH oxidase on a novel, pre-phagosomal compartment during FcR-mediated phagocytosis in primary mouse neutrophils. Blood 2010, 116, 4978-4989. [CrossRef] [PubMed]

146. Ameziane-El-Hassani, R.; Morand, S.; Boucher, J.L.; Frapart, Y.M.; Apostolou, D.; Agnandji, D.; Gnidehou, S.; Ohayon, R.; Noel-Hudson, M.S.; Francon, J.; et al. Dual oxidase-2 has an intrinsic Ca2+-dependent H2O2-generating activity. J. Biol. Chem. 2005, 280, 30046-30054. [CrossRef]

147. Morand, S.; Ueyama, T.; Tsujibe, S.; Saito, N.; Korzeniowska, A.; Leto, T.L. Duox maturation factors form cell surface complexes with Duox affecting the specificity of reactive oxygen species generation. Faseb J. 2009, 23, 1205-1218. [CrossRef] 
148. Takac, I.; Schroder, K.; Zhang, L.; Lardy, B.; Anilkumar, N.; Lambeth, J.D.; Shah, A.M.; Morel, F.; Brandes, R.P. The E-loop is involved in hydrogen peroxide formation by the NADPH oxidase Nox4. J. Biol. Chem. 2011, 286, 13304-13313. [CrossRef]

149. Hoste, C.; Dumont, J.E.; Miot, F.; De Deken, X. The type of DUOX-dependent ROS production is dictated by defined sequences in DUOXA. Exp. Cell Res. 2012, 318, 2353-2364. [CrossRef]

150. Nisimoto, Y.; Diebold, B.A.; Cosentino-Gomes, D.; Lambeth, J.D. Nox4: A hydrogen peroxide-generating oxygen sensor. Biochemistry 2014, 53, 5111-5120. [CrossRef]

151. Ueyama, T.; Sakuma, M.; Ninoyu, Y.; Hamada, T.; Dupuy, C.; Geiszt, M.; Leto, T.L.; Saito, N. The extracellular A-loop of dual oxidases affects the specificity of reactive oxygen species release. J. Biol. Chem. 2015, 290, 6495-6506. [CrossRef] [PubMed]

152. Ueyama, T.; Geiszt, M.; Leto, T.L. Involvement of Rac1 in activation of multicomponent Nox1- and Nox3-based NADPH oxidases. Mol. Cell Biol. 2006, 26, 2160-2174. [CrossRef] [PubMed]

153. Miyano, K.; Sumimoto, H. Role of the small GTPase Rac in p22phox-dependent NADPH oxidases. Biochimie 2007, 89, 1133-1144. [CrossRef] [PubMed]

154. Cheng, G.; Diebold, B.A.; Hughes, Y.; Lambeth, J.D. Nox1-dependent reactive oxygen generation is regulated by Rac1. J. Biol. Chem. 2006, 281, 17718-17726. [CrossRef]

155. Miyano, K.; Ueno, N.; Takeya, R.; Sumimoto, H. Direct involvement of the small GTPase Rac in activation of the superoxide-producing NADPH oxidase Nox1. J. Biol. Chem. 2006, 281, 21857-21868. [CrossRef]

156. Wu, W.; Hsu, Y.M.; Bi, L.; Songyang, Z.; Lin, X. CARD9 facilitates microbe-elicited production of reactive oxygen species by regulating the LyGDI-Rac1 complex. Nat. Immunol. 2009, 10, 1208-1214. [CrossRef]

157. Pick, E. Role of the Rho GTPase Rac in the activation of the phagocyte NADPH oxidase: Outsourcing a key task. Small GTPases 2014, 5, e27952. [CrossRef]

158. Ugolev, Y.; Berdichevsky, Y.; Weinbaum, C.; Pick, E. Dissociation of Rac1(GDP).RhoGDI complexes by the cooperative action of anionic liposomes containing phosphatidylinositol 3,4,5-trisphosphate, Rac guanine nucleotide exchange factor, and GTP. J. Biol. Chem. 2008, 283, 22257-22271. [CrossRef]

159. Yeung, T.; Gilbert, G.E.; Shi, J.; Silvius, J.; Kapus, A.; Grinstein, S. Membrane phosphatidylserine regulates surface charge and protein localization. Science 2008, 319, 210-213. [CrossRef]

160. Dovas, A.; Choi, Y.; Yoneda, A.; Multhaupt, H.A.; Kwon, S.H.; Kang, D.; Oh, E.S.; Couchman, J.R. Serine 34 phosphorylation of rho guanine dissociation inhibitor (RhoGDIa) links signaling from conventional protein kinase C to RhoGTPase in cell adhesion. J. Biol. Chem. 2010, 285, 23296-23308. [CrossRef]

161. DerMardirossian, C.; Schnelzer, A.; Bokoch, G.M. Phosphorylation of RhoGDI by Pak1 mediates dissociation of Rac GTPase. Mol. Cell 2004, 15, 117-127. [CrossRef] [PubMed]

162. DerMardirossian, C.; Rocklin, G.; Seo, J.Y.; Bokoch, G.M. Phosphorylation of RhoGDI by Src regulates Rho GTPase binding and cytosol-membrane cycling. Mol. Biol. Cell. 2006, 17, 4760-4768. [CrossRef] [PubMed]

163. Mack, N.A.; Whalley, H.J.; Castillo-Lluva, S.; Malliri, A. The diverse roles of Rac signaling in tumorigenesis. Cell Cycle 2011, 10, 1571-1581. [CrossRef] [PubMed]

164. Hirata, E.; Yukinaga, H.; Kamioka, Y.; Arakawa, Y.; Miyamoto, S.; Okada, T.; Sahai, E.; Matsuda, M. In vivo fluorescence resonance energy transfer imaging reveals differential activation of Rho-family GTPases in glioblastoma cell invasion. J. Cell Sci. 2012, 125, 858-868. [CrossRef]

165. Yukinaga, H.; Shionyu, C.; Hirata, E.; Ui-Tei, K.; Nagashima, T.; Kondo, S.; Okada-Hatakeyama, M.; Naoki, H.; Matsuda, M. Fluctuation of Rac1 activity is associated with the phenotypic and transcriptional heterogeneity of glioma cells. J. Cell Sci. 2014, 127, 1805-1815. [CrossRef] [PubMed]

166. Ungefroren, H.; Witte, D.; Lehnert, H. The role of small GTPases of the Rho/Rac family in TGF-beta-induced EMT and cell motility in cancer. Dev. Dyn. 2018, 247, 451-461. [CrossRef] [PubMed]

167. Zhou, C.; Licciulli, S.; Avila, J.L.; Cho, M.; Troutman, S.; Jiang, P.; Kossenkov, A.V.; Showe, L.C.; Liu, Q.; Vachani, A.; et al. The Rac1 splice form Rac1b promotes K-ras-induced lung tumorigenesis. Oncogene 2013, 32, 903-909. [CrossRef] [PubMed]

168. Kotelevets, L.; Walker, F.; Mamadou, G.; Lehy, T.; Jordan, P.; Chastre, E. The Rac1 splice form Rac1b favors mouse colonic mucosa regeneration and contributes to intestinal cancer progression. Oncogene 2018, 37, 6054-6058. [CrossRef] [PubMed] 
169. Ishii, T.; Ueyama, T.; Shigyo, M.; Kohta, M.; Kondoh, T.; Kuboyama, T.; Uebi, T.; Hamada, T.; Gutmann, D.H.; Aiba, A.; et al. A Novel Rac1-GSPT1 Signaling Pathway Controls Astrogliosis Following Central Nervous System Injury. J. Biol. Chem. 2016, 292, 1240-1250. [CrossRef] [PubMed]

170. Kobayashi, T.; Funakoshi, Y.; Hoshino, S.; Katada, T. The GTP-binding release factor eRF3 as a key mediator coupling translation termination to mRNA decay. J. Biol. Chem. 2004, 279, 45693-45700. [CrossRef]

171. Hellen, C.U.T. Translation Termination and Ribosome Recycling in Eukaryotes. Cold Spring Harb. Perspect. Biol. 2018, 10. [CrossRef] [PubMed]

172. Yoshida, T.; Zhang, Y.; Rivera Rosado, L.A.; Chen, J.; Khan, T.; Moon, S.Y.; Zhang, B. Blockade of Rac1 activity induces G1 cell cycle arrest or apoptosis in breast cancer cells through downregulation of cyclin D1, survivin, and X-linked inhibitor of apoptosis protein. Mol. Cancer Ther. 2010, 9, 1657-1668. [CrossRef] [PubMed]

173. Liu, L.; Zhang, H.; Shi, L.; Zhang, W.; Yuan, J.; Chen, X.; Liu, J.; Zhang, Y.; Wang, Z. Inhibition of Rac1 activity induces G1/S phase arrest through the GSK3/cyclin D1 pathway in human cancer cells. Oncol. Rep. 2014, 32, 1395-1400. [CrossRef] [PubMed]

174. Litchfield, K.; Holroyd, A.; Lloyd, A.; Broderick, P.; Nsengimana, J.; Eeles, R.; Easton, D.F.; Dudakia, D.; Bishop, D.T.; Reid, A.; et al. Identification of four new susceptibility loci for testicular germ cell tumour. Nat. Commun. 2015, 6, 8690. [CrossRef] [PubMed]

175. Xiao, R.; Li, C.; Chai, B. miRNA-144 suppresses proliferation and migration of colorectal cancer cells through GSPT1. Biomed. Pharmacother 2015, 74, 138-144. [CrossRef]

176. Matyskiela, M.E.; Lu, G.; Ito, T.; Pagarigan, B.; Lu, C.C.; Miller, K.; Fang, W.; Wang, N.Y.; Nguyen, D.; Houston, J.; et al. A novel cereblon modulator recruits GSPT1 to the CRL4(CRBN) ubiquitin ligase. Nature 2016, 535, 252-257. [CrossRef] [PubMed]

177. Nair, S.; Bora-Singhal, N.; Perumal, D.; Chellappan, S. Nicotine-mediated invasion and migration of non-small cell lung carcinoma cells by modulating STMN3 and GSPT1 genes in an ID1-dependent manner. Mol. Cancer 2014, 13, 173. [CrossRef] [PubMed]

178. Jerbi, S.; Jolles, B.; Bouceba, T.; Jean-Jean, O. Studies on human eRF3-PABP interaction reveal the influence of eRF3a N-terminal glycin repeat on eRF3-PABP binding affinity and the lower affinity of eRF3a 12-GGC allele involved in cancer susceptibility. RNA Biol. 2016, 13, 306-315. [CrossRef] [PubMed]

179. Brito, M.; Malta-Vacas, J.; Carmona, B.; Aires, C.; Costa, P.; Martins, A.P.; Ramos, S.; Conde, A.R.; Monteiro, C. Polyglycine expansions in eRF3/GSPT1 are associated with gastric cancer susceptibility. Carcinogenesis 2005, 26, 2046-2049. [CrossRef]

180. Malta-Vacas, J.; Chauvin, C.; Goncalves, L.; Nazare, A.; Carvalho, C.; Monteiro, C.; Bagrel, D.; Jean-Jean, O.; Brito, M. eRF3a/GSPT1 12-GGC allele increases the susceptibility for breast cancer development. Oncol. Rep. 2009, 21, 1551-1558. [PubMed]

181. Miri, M.; Hemati, S.; Safari, F.; Tavassoli, M. GGCn polymorphism of eRF3a/GSPT1 gene and breast cancer susceptibility. Med. Oncol. 2012, 29, 1581-1585. [CrossRef] [PubMed]

182. Chiba, S.; Enami, T.; Ogawa, S.; Sakata-Yanagimoto, M. G17V RHOA: Genetic evidence of GTP-unbound RHOA playing a role in tumorigenesis in T cells. Small GTPases 2015, 6, 100-103. [CrossRef] [PubMed]

183. Bustelo, X.R. Vav family exchange factors: An integrated regulatory and functional view. Small GTPases 2014, 5, 9. [CrossRef]

184. Vallois, D.; Dobay, M.P.; Morin, R.D.; Lemonnier, F.; Missiaglia, E.; Juilland, M.; Iwaszkiewicz, J.; Fataccioli, V.; Bisig, B.; Roberti, A.; et al. Activating mutations in genes related to TCR signaling in angioimmunoblastic and other follicular helper T-cell-derived lymphomas. Blood 2016, 128, 1490-1502. [CrossRef] [PubMed]

185. Boddicker, R.L.; Razidlo, G.L.; Dasari, S.; Zeng, Y.; Hu, G.; Knudson, R.A.; Greipp, P.T.; Davila, J.I.; Johnson, S.H.; Porcher, J.C.; et al. Integrated mate-pair and RNA sequencing identifies novel, targetable gene fusions in peripheral T-cell lymphoma. Blood 2016, 128, 1234-1245. [CrossRef] [PubMed]

186. Abate, F.; da Silva-Almeida, A.C.; Zairis, S.; Robles-Valero, J.; Couronne, L.; Khiabanian, H.; Quinn, S.A.; Kim, M.Y.; Laginestra, M.A.; Kim, C.; et al. Activating mutations and translocations in the guanine exchange factor VAV1 in peripheral T-cell lymphomas. Proc. Natl. Acad Sci. USA 2017, 114, 764-769. [CrossRef] 
187. Fujisawa, M.; Sakata-Yanagimoto, M.; Nishizawa, S.; Komori, D.; Gershon, P.; Kiryu, M.; Tanzima, S.; Fukumoto, K.; Enami, T.; Muratani, M.; et al. Activation of RHOA-VAV1 signaling in angioimmunoblastic T-cell lymphoma. Leukemia 2018, 32, 694-702. [CrossRef]

188. Lopes, F.; Barbosa, M.; Ameur, A.; Soares, G.; de Sa, J.; Dias, A.I.; Oliveira, G.; Cabral, P.; Temudo, T.; Calado, E.; et al. Identification of novel genetic causes of Rett syndrome-like phenotypes. J. Med. Genet. 2016, 53, 190-199. [CrossRef]

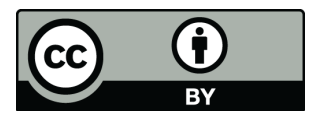

(C) 2019 by the author. Licensee MDPI, Basel, Switzerland. This article is an open access article distributed under the terms and conditions of the Creative Commons Attribution (CC BY) license (http://creativecommons.org/licenses/by/4.0/). 